\title{
A modular approach for the installation of functionalized phosphonates to heterocycles
}

\author{
Zachary Shultz, ${ }^{a}$ Chuan Shan, ${ }^{\mathrm{c}}$ Lukasz Wojtas, ${ }^{\mathrm{c}}$ and Justin M. Lopchuk*a,b,c \\ a Drug Discovery Department, H. Lee Moffitt Cancer Center and Research Institute, \\ 12902 Magnolia Drive, Tampa, Florida 33612, USA \\ ${ }^{b}$ Department of Oncologic Sciences, College of Medicine, University of South Florida, \\ Tampa, Florida 33612, USA \\ c Department of Chemistry, University of South Florida, Tampa, Florida 33620, USA \\ Email: justin.lopchuk@moffitt.org
}

Dedicated to Prof. Peter A. Jacobi on the occasion of his retirement from Dartmouth College

Received 02-05-2021

Accepted 03-07-2021

Published on line 03-11-2021

\begin{abstract}
Phosphonic acids and esters are pervasive throughout the discovery sciences, from medicine and agriculture, to materials and asymmetric synthesis. The ability to install and construct molecular architecture containing phosphonic functionality has led to the development of new medicines and catalyst systems in the field of organo- and organometallic catalysis. To continue the advancement in the field, improved synthetic access to phosphorous-containing motifs is required. In particular, heterocyclic phosphonates and their acid derivatives are so far underdeveloped. The method described herein provides a robust and operationally simple procedure for the installation of various phosphonates to a wide range of electrophilic heterocycles.
\end{abstract}

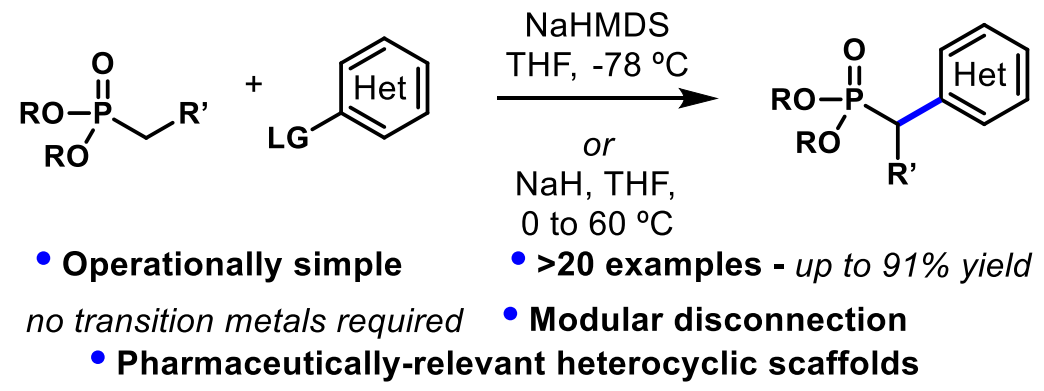

[Biologically active analogs]

Keywords: Phosphonates, heterocycles, $S_{N} A r$, transition metal-free, ANRORC 


\section{Introduction}

Phosphorus-containing compounds are ubiquitous in nature and have a myriad of uses in medicinal and agricultural chemistry, ${ }^{1-3}$ material sciences, ${ }^{4,5}$ organocatalytic and organometallic chemistry ${ }^{6-10}$ While phosphonic acids have been regarded as formidable organocatalysts for a variety of Lewis acid-mediated transformations, ${ }^{11,12}$ phosphonates have been shown as useful ligands for organometallic transformations. ${ }^{9}$ Phosphonates also serve as practical synthetic reagents for the Horner-Wadsworth-Emmons (HWE) olefination utilized in countless chemical syntheses. ${ }^{13}$ Perhaps one of the most well-known and clinically important phosphonates is tenofovir (1, Viread), which is currently prescribed as a treatment for hepatitis B and HIV/AIDS. ${ }^{14,15}$ Other phosphonates, such as $\mathbf{2 - 4}$ in Figure 1, are known to play a role in biological systems by interacting with calcium channels and phosphatases, ${ }^{16,17}$ with fostedil (4) having been developed as a vasodilator for angina and antihypertensive indications. ${ }^{18,19}$

Utilization of arylmethyl phosphonates transcends clinical applications into material and agricultural sciences, such as spirocyclic bisphosphonate $(5)^{5}$ and heterocyclic-containing phosphonates $(6 \text { and } 7)^{20,21}$ respectively. The recent report of the anti-tumor activity of 2,6-diaminopyridylmethyl phosphonate $8,{ }^{22}$ and the method for its preparation, ${ }^{23,24}$ further exemplifies the need for new general methods for the synthesis of heterocyclic analogs. Examples of $\alpha$-arylated phosphonates (2-5 and 7) are rather common while heterocyclic $\alpha$-arylated phosphonates (6 and 8 ) are scarcely reported or evaluated. The lack of heterocyclic $\alpha$-arylated phosphonates can be attributed to an absence of synthetic access to these promising scaffolds.

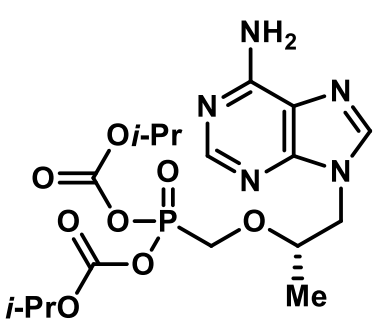

Tenofovir disoproxil (1) reverse transcriptase inhibitor

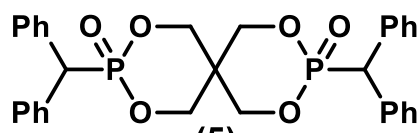

(5)

flame retardant materials<smiles>CCOP(=O)(OCC)C(c1ccc(F)cc1)c1ccc(F)cc1</smiles>

calcium channel antagonist<smiles>CCOP(=O)(OCC)C(c1nc(Cl)cc(C(C)C)n1)c1ccccc1Cl</smiles>
fungicide<smiles>O=P(O)(O)C(c1ccccc1)c1ccccc1C(F)(F)F</smiles>

(3)

phosphatase inhibitor

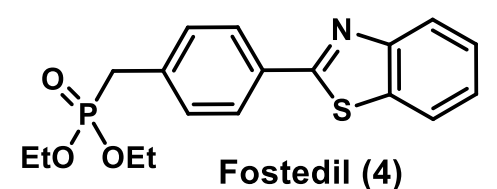

calcium channel blocker

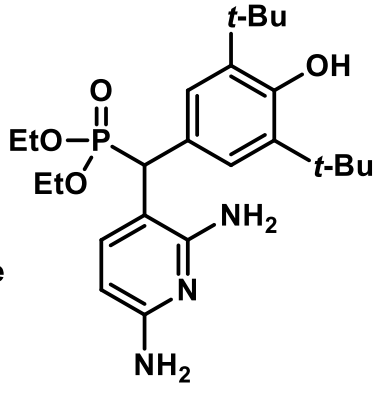

(8)

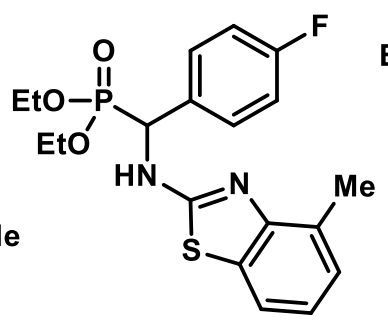

Dufulin (7) anti-viral pesticide

Figure 1. Biologically and industrially relevant phosphonate and phosphonic acids.

Classical approaches to phosphonates (alkyl or aryl) rely on the Michaelis-Arbuzov or Michaelis-Becker reactions using trialkyl- or disubstituted phosphites with alkyl halides and extreme thermal conditions or basic conditions, respectively (Figure 2A). ${ }^{25,26}$ More modern methods utilize transition metal catalysis to forge a new $\mathrm{C}-\mathrm{C}$ bond (red) at the $\alpha$-position with aryl halides (Figure 2B). ${ }^{27-31}$ The use of stochiometric metals and excess phosphonate are usually required with one known palladium-catalyzed report using exotic catalytic systems. ${ }^{31}$ Despite the advancements in organometallic catalysis for the $\alpha$-arylations of phosphonates, the heterocycle scope is still severely limited, hindering access to the heterocyclic $\alpha$-arylated phosphonates. 


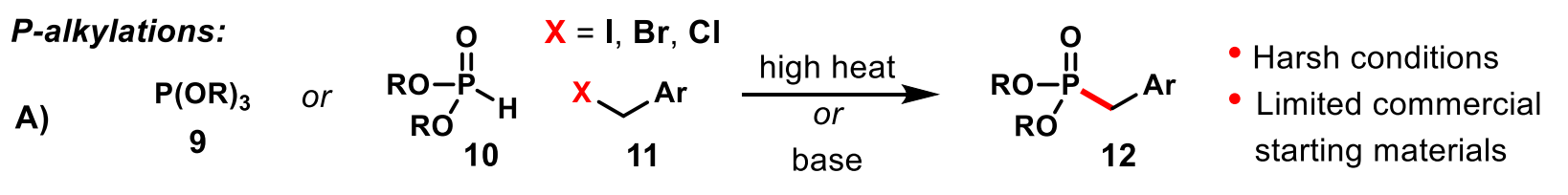

Transition metal

B)<smiles>[R6][PH]([R6])([13CH3])CC(C)(C)C#N</smiles>

$\mathrm{EWG}=\mathrm{CO}_{2} \mathrm{Et}, \mathrm{SO}_{2} \mathrm{Me}, \mathrm{CN}, \mathrm{COMe}, \mathrm{Ph}$
[M], base,

$\underset{14}{\mathrm{Ar}-\mathrm{X}} \underset{[\mathrm{M}]=\mathrm{Fe}, \mathrm{Cu}, \mathrm{Zn} \text { or } \mathrm{Pd}}{\stackrel{\text { ligand }}{\longrightarrow}}$

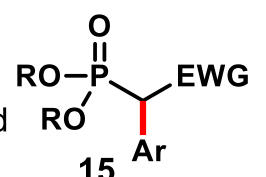

- Limited heterocycle scope

- Stoichiometric [M] (one Pd cat. example)

- Exotic alkyl phosphine ligands required ( $\mathrm{Pd}$ cat.)

$S_{N} A r$ of phosphonate -anions:

C)<smiles>[Y]CP([R6])([R6])=O</smiles>
$\mathbf{Y}=\mathbf{C l}, \mathbf{P h}$<smiles>O=[N+]([O-])c1ccccc1</smiles>

17

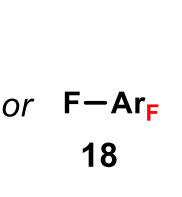

18

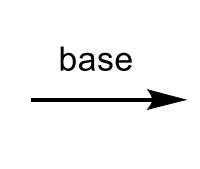<smiles>[R]OP(=O)(Cc1cccc([N+](=O)[O-])c1)O[Na]</smiles>

(mixture of regioisomers)

- Limited electrophile scope $•$ Limited phosphonate scope

- Particular niche products

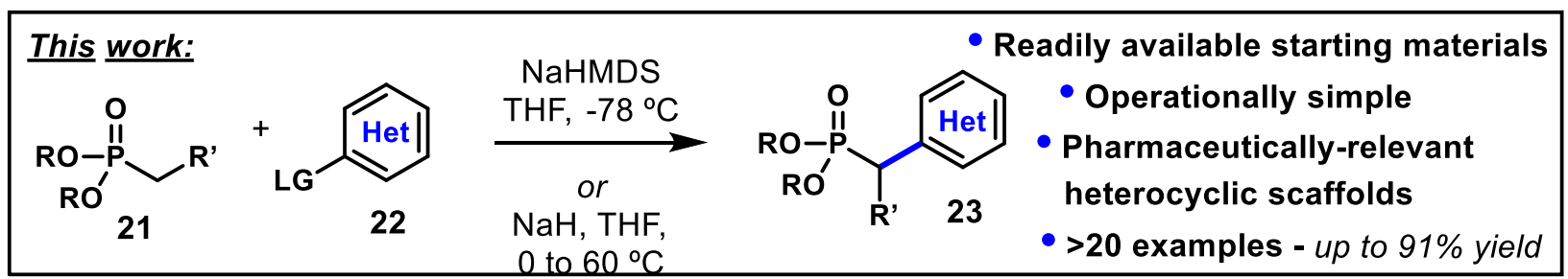

Figure 2. Classical and modern methods for preparing $\alpha$-arylated phosphonates compared to this work.

One of the most useful and simple tactics for the installation of heterocyclic motifs is via nucleophilic aromatic substitution $\left(S_{N} A r\right)$. Phosphonates bearing $\alpha$-hydrogens are capable of undergoing deprotonation with a suitable base to provide anions with the ability to partake in traditional addition and substitution chemistry as well as the HWE olefination. ${ }^{32-34}$ These "enolate-like" phosphonate anions have been used as viable nucleophilic surrogates for $S_{N} A r$ chemistry (Figure $2 \mathrm{C}$ ) with a very limited phosphonate and electrophile scope, ${ }^{35,36}$ rendering the method useful only for niche applications. In order to broaden the phosphonate heterocyclic chemical space, a robust and operationally simple $S_{N} A r$ procedure was developed from readily available phosphonates and electrophilic heterocycles.

\section{Results and Discussion}

To apply a modular approach toward the synthesis of phosphonate-containing heterocycles, similar to the structures found in Figure 1, a general and, ideally, operationally simple synthetic procedure was required. Screening was conducted on stabilized and non-stabilized phosphonates since both 1) are readily available (most commercially), 2) have a drastic difference in the pKa of the $\alpha$-protons (>29 to 18$)^{37,38}$ and 3 ) exhibit utility of the products. A variety of bases and reaction conditions were screened with commercially available phosphonates (Table 1) and 4,6-dichloropyrimidine 24. For methyl phosphonates (lacking anion stabilizing substituents), the base, temperature and reaction time were critical to achieve high consumption of the heterocyclic electrophile (entries 1-6). Interestingly, the order of addition had very little impact on the overall reaction outcomes. For example, the addition of pyrimidine 24 to a preformed phosphonate anion at $-78{ }^{\circ} \mathrm{C}$ 
provided nearly identical product distributions as compared to the addition of base to a mixture of phosphonate and pyrimidine $\mathbf{2 4}$ - thus providing an operationally simple procedure.

For non-stabilized phosphonates, NaHMDS proved to be superior (entry 3) to the other bases including LiHMDS (entry 4), KHMDS (entry 5 ) and $n$-BuLi (entry 6). Although the reaction can occur at $-78{ }^{\circ} \mathrm{C}$, low to moderate conversion was observed after 8 hours and the reactions were warmed to room temperature to achieve high conversions and good isolated yield (see experimental section for more information). The optimized equivalents of base and reaction temperatures are depicted in Table 1 for three different phosphonate types used. In each case, 2.2 equivalents of base provided high to full conversion of pyrimidine 24. Phosphonates containing electron stabilizing groups $\left(\mathrm{CO}_{2} \mathrm{Et}\right.$, benzylic) can undergo the $\mathrm{S}_{N} A r$ reaction using $\mathrm{NaH}$ at room temperature or $60^{\circ} \mathrm{C}$. For triethyl acetophosphonate (entry 8) $\mathrm{NaH}$ as the base was determined to be optimal (75\% isolated yield) compared to NaHMDS (entry 7), while diethyl (4-chlorobenzyl)phosphonate gave full consumption with NaHMDS and 91\% isolated yield (entry 9) instead of NaH (entry 10).

Table 1. Optimization of phosphonate $S_{N} A r$ reaction with various phosphonate nucleophiles
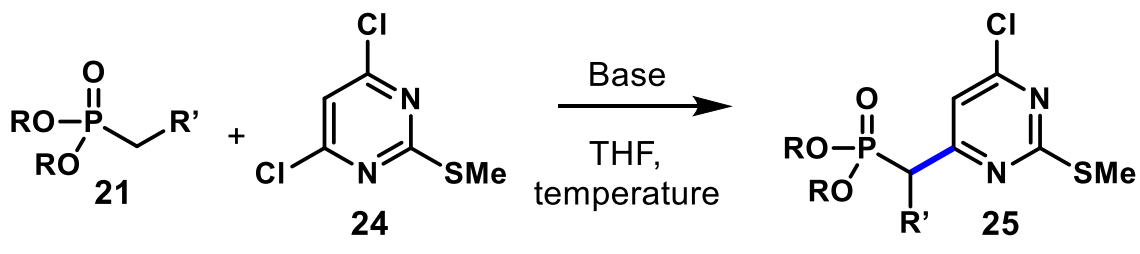

\begin{tabular}{|c|c|c|c|c|c|c|c|}
\hline Entry & $\mathrm{R}=$ & $\mathrm{R}^{\prime}=$ & Base & equivalents & temperature ${ }^{a}$ & conversion $^{b}$ & $\%$ yield $^{c}$ \\
\hline 1 & $\mathrm{Me}$ & $\mathrm{H}$ & NaHMDS & $1.1 \mathrm{eq}$. & $-78{ }^{\circ} \mathrm{C}$ to rt & $<50 \%$ & - \\
\hline 2 & $\mathrm{Me}$ & $\mathrm{H}$ & NaHMDS & $2.2 \mathrm{eq}$. & $-78^{\circ} \mathrm{C}$ & $<50 \%$ & - \\
\hline 3 & $\mathrm{Me}$ & $\mathrm{H}$ & NaHMDS & $2.2 \mathrm{eq}$. & $-78^{\circ} \mathrm{C}$ to rt & $>90 \%$ & $78 \%$ \\
\hline 4 & $\mathrm{Me}$ & $\mathrm{H}$ & LiHMDS & $2.2 \mathrm{eq}$. & $-78^{\circ} \mathrm{C}$ to rt & $>25 \%$ & - \\
\hline 5 & $\mathrm{Me}$ & $\mathrm{H}$ & KHMDS & $2.2 \mathrm{eq}$. & $-78^{\circ} \mathrm{C}$ to rt & $\leq 75 \%$ & $52 \%$ \\
\hline 6 & $\mathrm{Me}$ & $\mathrm{H}$ & n-BuLi & $1 \mathrm{eq}$. & $-78^{\circ} \mathrm{C}$ to rt & $<50 \%$ & - \\
\hline 7 & Et & $\mathrm{CO}_{2} \mathrm{Et}$ & NaHMDS & $2.2 \mathrm{eq}$. & 0 to $60^{\circ} \mathrm{C}$ & $>25 \%$ & - \\
\hline 8 & Et & $\mathrm{CO}_{2} \mathrm{Et}$ & $\mathrm{NaH}$ & $2.2 \mathrm{eq}$. & 0 to $60^{\circ} \mathrm{C}$ & $>75 \%$ & $75 \%$ \\
\hline 9 & Et & $\begin{array}{c}\mathrm{Bn} \\
(4-\mathrm{Cl})\end{array}$ & NaHMDS & $2.2 \mathrm{eq}$ & $-78{ }^{\circ} \mathrm{C}$ to rt & $99 \%$ & $91 \%$ \\
\hline 10 & Et & $\begin{array}{c}\mathrm{Bn} \\
(4-\mathrm{Cl})\end{array}$ & $\mathrm{NaH}$ & $2.2 \mathrm{eq}$. & $-78^{\circ} \mathrm{C}$ to rt & $>25 \%$ & - \\
\hline
\end{tabular}

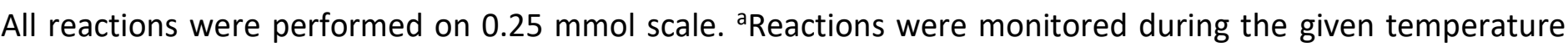
range to determine optimal temperature. ${ }^{b}$ Conversion estimated by LC/MS. Isolated yield.

With the optimal conditions in hand, a variety of phosphonate nucleophiles were screened using 4,6dichloropyrimidine $\mathbf{2 4}$ as the heterocyclic electrophile (Figure 2). Three different non-stabilized phosphonate esters (OMe, OEt, OBn) performed well under the optimized reaction conditions and could be subsequently functionalized at the $\alpha$-position based on the desired application. The commonly used and commercially available triethyl acetophosphonate was employed (as mentioned above) to give the SNAr product $\mathbf{2 8}$ in $\mathbf{7 5 \%}$ 
yield, where the ester functionality provides an additional diversifiable handle for further manipulations (decarboxylation, nucleophilic additions, etc.). Diethyl (cyanomethyl) phosphonate served as a viable nucleophile to afford $\mathbf{3 0}$ in an isolated yield of $88 \%$. The increased acidity of the remaining $\alpha$-proton and stabilization from hydrogen bonding interactions between the $\mathrm{N}-\mathrm{H}$ and $\mathrm{P}=\mathrm{O}$ resulted in isolation of a tautomeric form of the $S_{N} A r$ product $\mathbf{2 5}$, which was unambiguously determined by single crystal X-ray crystallography. ${ }^{39}$ Phosphonates bearing benzylic substituents all performed exceptionally well (31-35) and provide intermediates capable of downstream modifications (e.g. reduction of $\mathrm{NO}_{2}$ or cross-couplings with $\mathrm{sp}^{2}$-halides). The use of diethyl (4-fluorobenzy)phosphonate as a nucleophile is a noteworthy example due its biological implications in calcium channel antagonists such as $\mathbf{2}$ (Figure 1 ).
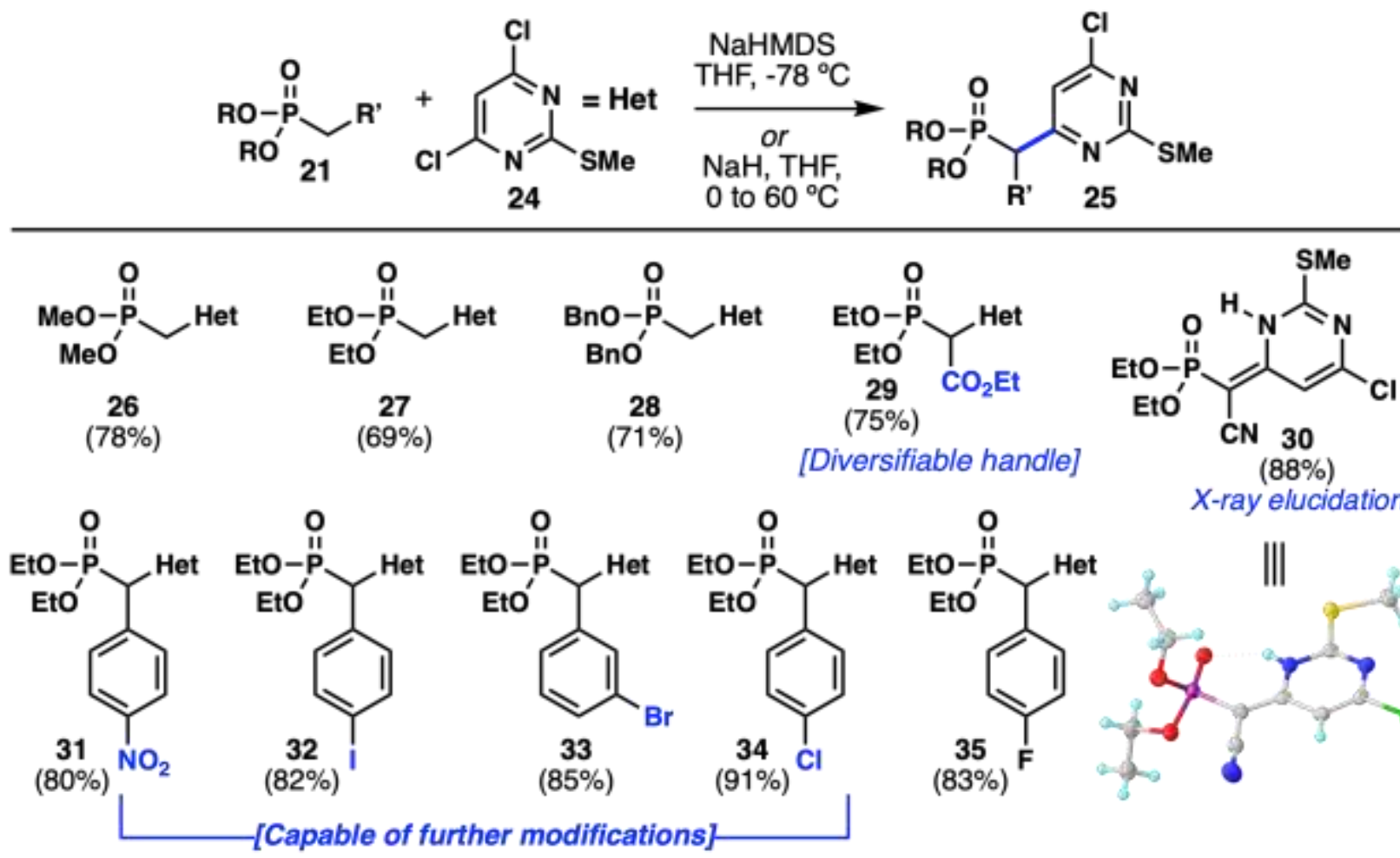

$(88 \%)$

$X$-ray elucidation
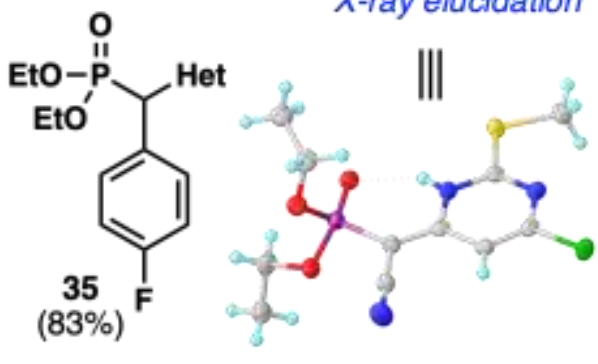

Figure 3. Phosphonate nucleophile scope for $S_{N} A r$ reactions with pyrimidine 24 . All reactions were performed on $0.25 \mathrm{mmol}$ scale with 2.2 eq. of NaHMDS or NaH. All yields are reported as isolated yields.

The electrophile scope was expanded to include heterocycles commonly used in drug discovery and material sciences. Triazines, pyrimidines and pyridines make up much of the heterocyclic scaffolds employed within the discovery sciences due to their commercial availability and their use in a wide variety of $S_{N} A r$ and cross-coupling reactions. ${ }^{40}$ Therefore, an emphasis was placed on pyrimidine and pyridine scaffolds and their regioselective functionalization as seen in Figure 3. A morpholine-containing triazine, a popular scaffold in medicinal chemistry, ${ }^{41}$ underwent the phosphonate $S_{N} A r$ smoothly with a non-stabilized phosphonate to provide 36 in 90\% yield. Versatile pyrimidine building block 24 provided 26 in good yield with trimethyl phosphonate. Electron rich 2-chloro-4,6-dimethoxypyrimidine and a 2-naphthyl 4,6-dichloropyrimidine can also undergo the $S_{N} A r$ with trimethyl phosphonate to give $\mathbf{3 7}$ and $\mathbf{3 8}$ respectively - producing products capable of later functionalization Site-selective reactivity was demonstrated by using 4,6-dichloro-2(methylsulfonyl)pyrimidine ( $\mathrm{LG}=\mathrm{SO}_{2} \mathrm{Me}$ ) (39 and 40 ) with exclusive substitution at $\mathrm{C}-2$. This regioselective $\mathrm{S}_{\mathrm{N}} \mathrm{Ar}$ provides a late-stage intermediate to analogs of known fungicide 6 via pyrimidine 39. Benzyl protected 6- 
chloropurine underwent the $S_{N} A r$ with triethyl acetophosphonate smoothly to access $\mathbf{4 1}$ in moderate yield. $A$ methylene variant of $\mathbf{4 1}$ (without $\mathrm{CO}_{2} \mathrm{Et}$ ) has been previously prepared in 4 steps from commercially available reagents, ${ }^{42}$ a stark contrast to the use of phosphonate $\alpha$-anion $S_{N} A r$. The methylene variant can theoretically be made accessible using an $S_{N} A r$-decarboxylation sequence (2 steps).
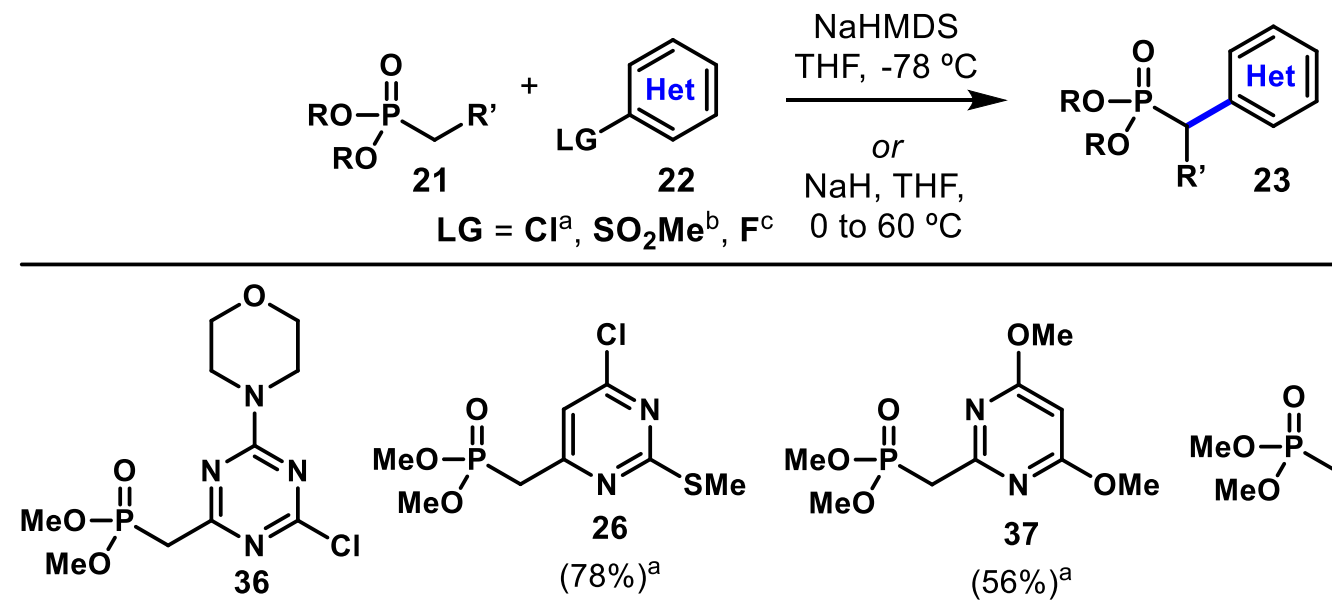<smiles>COP(=O)(Cc1cc(Cl)nc(SC)n1)OC</smiles>

$(78 \%)^{\mathrm{a}}$<smiles>COc1cc(OC)nc(CP(=O)(OC)OC)n1</smiles>

37

$(56 \%)^{\mathrm{a}}$<smiles>COP(=O)(Cc1cc(Cl)nc(-c2cccc3ccccc23)n1)OC</smiles>

$(48 \%)^{a}$<smiles>CCOP(=O)(OCC)C(c1ccc(Cl)cc1)C(c1nc(Cl)cc(Cl)n1)P(=O)(OCC)OCCO</smiles><smiles>CCOC(=O)C(c1ncnc2c1ncn2Cc1ccccc1)P(=O)(OCC)OCC</smiles>

41

$(66 \%)^{a}$<smiles>CCOP(=O)(OCC)C(c1ccc(F)cc1)c1ncccn1</smiles><smiles>CCOP(=O)(OCC)C(c1ccc(F)cc1)c1ccc(C(F)(F)F)cn1</smiles>

$(81 \%)^{\mathrm{a}}$<smiles>CCOP(=O)(OCC)C(c1ccc(F)cc1)c1ccnc(Cl)c1</smiles><smiles>CCOP(=O)(OCC)C(c1ccc(F)cc1)c1cc(Cl)nc(Cl)c1</smiles><smiles>CCOP(=O)(OCC)C(c1ccc(F)cc1)c1nc2ccccc2s1</smiles>

[calcium channel antagonist analogs]

Figure 4. Phosphonate electrophile scope for $S_{N} A r$ reactions with electrophilic heterocycles. All reactions were performed on $0.25 \mathrm{mmol}$ scale with 2.2 eq. of NaHMDS or $\mathrm{NaH}$. All yields are reported as isolated yields.

Diethyl (4-fluorobenzyl)phosphonate, previously shown to be an exceptional phosphonate nucleophile with pyrimidine 24 (Figure 3, 35), underwent the $S_{N} A r$ with 2-chloropyrimidine to give $\mathbf{4 2}$ in moderate yield and directly serves as a heterocyclic analog of calcium channel antagonist 2 . Electron-deficient pyridines were also excellent substrates for stabilized phosphonate anionic nucleophiles. 2-Chloro-5-trifluoromethyl-, 2,4dichloro-, and 2,4,6-trichloro-pyridines furnished respectively the phosphonates 43, 44, and 45, which can be further functionalized to extend the breadth of heterocyclic analogs of $\mathbf{2}$. Regioselectivity in the pyridine series of electrophiles was exploited using fluoride and $\mathrm{SO}_{2} \mathrm{Me}$ as leaving groups in the presence of the less suitable chloride leaving groups. Commercially available 4-fluoro-2-chloropyridine gave C-4 selective substitution of 
the fluoride in high yield $(44,80 \%)$ with trace amounts of chloride substitution ( $5 \%)$. Conversely, the $\mathrm{SO}_{2} \mathrm{Me}$ was selectively substituted in the presence of two other chloride leaving groups to provide $\mathbf{4 5}$ in good yield. Lastly, 2-chlorobenzothiazole proved to be a well-suited electrophile resulting in the direct synthesis of 46 , a hybrid analog of fostedil $\mathbf{4}$ and calcium channel antagonist $\mathbf{2}$.

A noteworthy example is that of 2-chloro-5-nitropyridine 48, in which an unexpected result occurred when treated with triethyl acetophosphonate $\mathbf{4 7}$ and $\mathrm{NaH}$ in THF at room temperature (heating to $60{ }^{\circ} \mathrm{C}$ accelerated the reaction without diminishment of overall yield, Figure 5). Instead of the expected $S_{N} A r$ product, the main isolated compound was ring-opened $\mathbf{5 0}$ (confirmed by single crystal X-ray structure). The phosphonate anion is thought to undergo an anionic ring-opening ring-closing (ANRORC)-type mechanism, known to occur with $\mathbf{4 8}$ in the presence of ${ }^{-} \mathrm{OH}$ or $\mathrm{NH}_{3}{ }^{43,44}$ It is proposed that the addition of anionic 47 to $\mathrm{C}-5$ of pyridine 48 leads to stabilized anionic intermediate 52/53 that undergoes a second deprotonation with $\mathrm{NaH}$. The newly formed anion results in $\mathrm{C}-\mathrm{N}$ bond cleavage and elimination of $\mathrm{Cl}^{-}$to provide a second stabilized anionic intermediate 55/56 that subsequently isomerizes to the more thermodynamically stable phosphonate 50. Further ring-closure that is typical of an ANRORC mechanism did not occur and a sodium salt of phosphonate $\mathbf{5 0}$ was isolated in $67 \%$ yield.
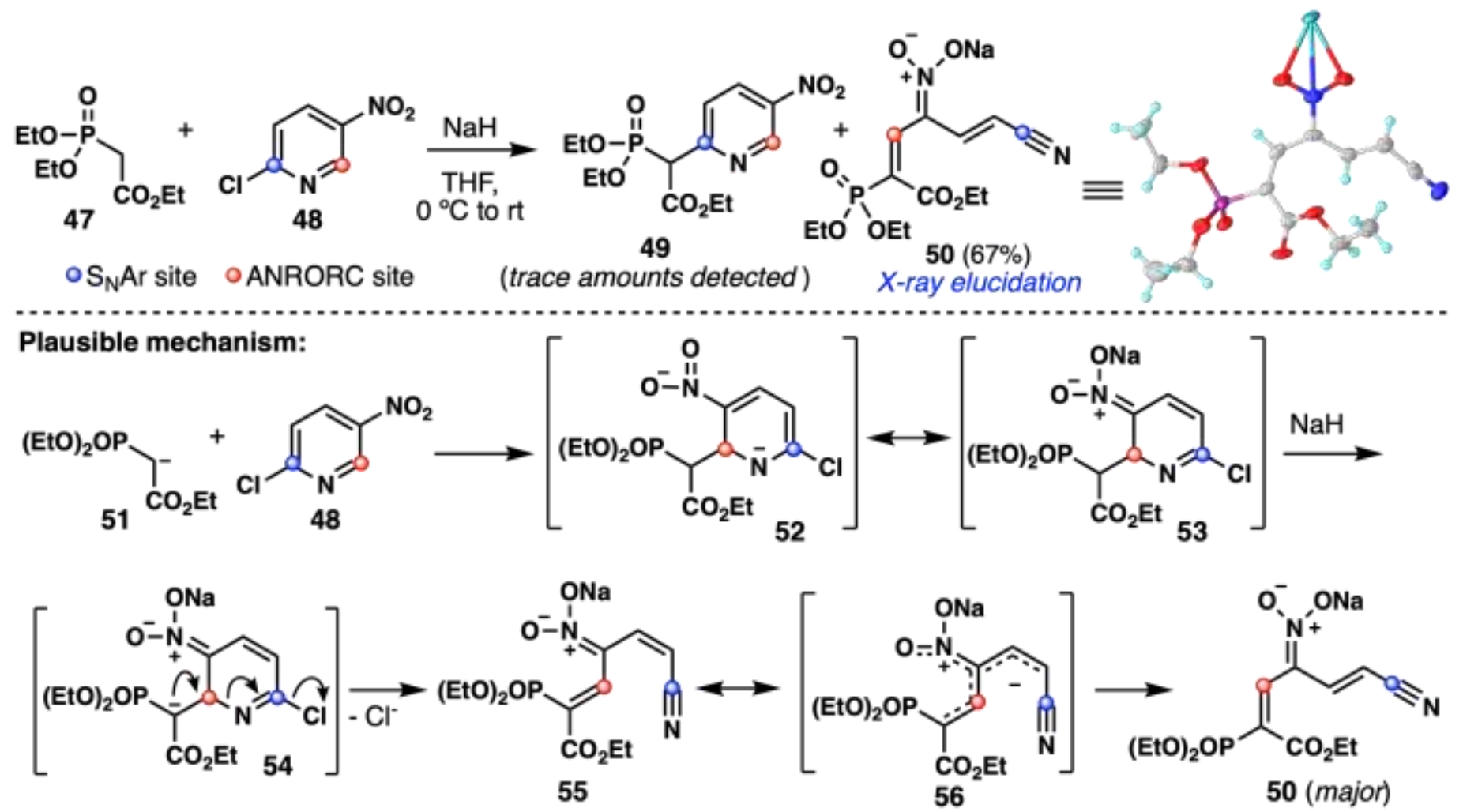

Figure 5. The reaction between anionic triethyl acetophosphonate $\mathbf{4 7}$ and 2-chloro-5-nitropyridine $\mathbf{4 8}$ via a postulated ANRORC-type mechanism.

\section{Conclusions}

Overall, a robust and modular method for the installation of phosphonates to pharmaceutically-relevant heterocycles via $S_{N} A r$ has been developed, quickly producing analogs of biologically active substrates. The operationally simple procedure allows for rapid screening and analog development. A range of commercially available phosphonates and electrophilic heterocycles were shown to be compatible as nucleophiles and 
electrophiles, further outlining the usefulness of this method. The results described herein suggest other heterocycles could also serve as viable electrophiles, expanding the overall phosphonate chemical space that can be readily accessed. This method provides a quick and simple route to heterocyclic phosphonates and should prove useful to drug discovery and agricultural chemistry in the future.

\section{Experimental Section}

General. Reagents were purchased at the highest commercial quality and used without further purification, unless otherwise stated. Anhydrous tetrahydrofuran (THF), acetonitrile (MeCN), and dimethylformamide (DMF) were obtained by passing the previously degassed solvent through an activated alumina column (PPT Glass Contour Solvent Purification System). Yields refer to chromatographically and spectroscopically $\left({ }^{1} \mathrm{H}\right.$ $\mathrm{NMR}$ ) homogeneous material, unless otherwise stated. Room temperature ( $\mathrm{rt}$ ) refers to ambient temperature in the laboratory (ca. $22-24{ }^{\circ} \mathrm{C}$ ). Reactions were monitored by LC/MS or thin layer chromatography (TLC) carried out on $250 \mu \mathrm{m}$ SiliCycle SiliaPlates (TLC Glass-Backed Extra Hard Layer, $60 \AA$ A), using shortwave UV light as the visualizing agent and iodine or $\mathrm{KMnO}_{4}$ and heat as developing agents when needed. Flash column chromatography was performed with a Biotage Isolera One (ZIP or SNAP Ultra cartridges) or with traditional glass flash columns using SiliCycle SiliaFlash ${ }^{\circledR}$ P60 (particle size 40-63 $\mu \mathrm{m}$ ). NMR spectra were recorded on a Bruker Ascend ${ }^{\mathrm{TM}} 500 \mathrm{MHz}$ spectrometer or Bruker Neo600 spectrometer and were calibrated using residual undeuterated solvent as an internal reference $\left(\mathrm{CDCl}_{3}\right.$ : $7.26 \mathrm{ppm}{ }^{1} \mathrm{H} \mathrm{NMR}, 77.16 \mathrm{ppm}{ }^{13} \mathrm{C} N \mathrm{NM}$; DMSO- $d_{6}: 2.50$ ppm ${ }^{1} \mathrm{H}$ NMR, 39.5 ppm ${ }^{13} \mathrm{C}$ NMR; MeOD: $3.31 \mathrm{ppm}{ }^{1} \mathrm{H}$ NMR, $49.0 \mathrm{ppm}{ }^{13} \mathrm{C}$ NMR). The following abbreviations were used to explain NMR peak multiplicities: $s=$ singlet, $d=$ doublet, $t=$ triplet, $p=$ pentet, $d d=$ doublet of doublets, $\mathrm{tt}=$ triplet of triplets, $\mathrm{dt}=$ doublet of triplets, $\mathrm{td}=$ triplet of doublets, $\mathrm{m}=$ multiplet, $\mathrm{br}=$ broad. Highresolution mass spectra (HRMS) were recorded on an Agilent 6230 LC-MS TOF mass spectrometer using electrospray ionization time-of-flight (ESI-TOF) reflection experiments. Melting points were recorded on a Chemglass DMP 100 melting point apparatus.

\section{Synthesis of phosphonate nucleophiles and heterocyclic electrophiles: Dibenzyl methylphosphonate (58)}

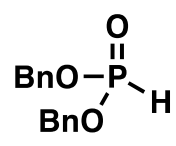

57

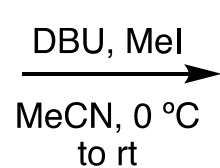

to $\mathrm{rt}$

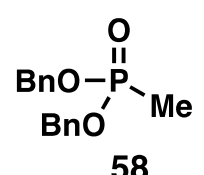

58

$(71 \%)$

In a septum capped $20 \mathrm{~mL}$ reaction vial equipped with a stir bar and argon balloon was added 57 (1.50 g, 5.72 mol, 1 eq.) and $\mathrm{MeCN}(11.5 \mathrm{~mL})$. The mixture was cooled to $0{ }^{\circ} \mathrm{C}$ and $\mathrm{Mel}(0.391 \mathrm{~mL}, 6.29 \mathrm{mmol}, 1.1$ eq.) was added followed by dropwise addition of DBU $(0.939 \mathrm{~mL}, 6.29 \mathrm{mmol}, 1.1 \mathrm{eq}$.). The reaction mixture stirred at 0 ${ }^{\circ} \mathrm{C}$ for 2 hours then warmed to room temperature where it stirred for 10 hours. The reaction mixture was diluted with MeCN $(10 \mathrm{~mL})$ and washed with hexanes $(25 \mathrm{~mL} \times 2)$. The MeCN layer was collected and the solvent removed under reduced pressure to give a crude oil that was further purified by silica gel column chromatography using hexanes/EtOAc (0\% to 50\% EtOAc gradient) to provide 58 (1.12 g, 4.05 mmol, 71\% yield) as a clear colorless oil. TLC: $\mathrm{R}_{f}=0.28$ (60\% EtOAc in hexanes, UV). ${ }^{1} \mathrm{H}$ NMR: $\left(600 \mathrm{MHz}, \mathrm{CDCl}_{3}\right) \delta 7.43-$ $7.29(\mathrm{~m}, 10 \mathrm{H}), 5.06$ (dd, J 11.9, $8.8 \mathrm{~Hz}, 2 \mathrm{H}), 4.97$ (dd, J 11.9, $8.4 \mathrm{~Hz}, 2 \mathrm{H}), 1.48(\mathrm{~d}, J 17.7 \mathrm{~Hz}, 3 \mathrm{H}) \mathrm{ppm} .{ }^{13} \mathrm{C} \mathrm{NMR}$ : 
$\left(126 \mathrm{MHz}, \mathrm{CDCl}_{3}\right) \delta 136.37$ (d, J $\left.6.0 \mathrm{~Hz}\right), 128.63,128.43,127.93,67.11$ (d, J $\left.6.2 \mathrm{~Hz}\right), 11.73$ (d, J 144.3 Hz). ${ }^{31} \mathrm{P}$ NMR: $\left(243 \mathrm{MHz}, \mathrm{CDCl}_{3}\right) \delta 31.70 \mathrm{ppm}$.

*Spectroscopic data are in accordance with the literature. ${ }^{26}$

\section{N-(4,6-Dichloro-1,3,5-triazin-2-yl)morpholine (61)}<smiles>Clc1nc(Cl)nc(Cl)n1</smiles>

59<smiles>C1COCCN1</smiles>

60

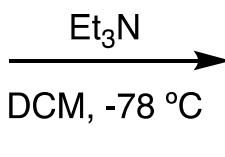

$(99 \%)$<smiles>Clc1nc(Cl)nc(N2CCOCC2)n1</smiles>

61

In a septum capped $200 \mathrm{~mL}$ round-bottomed flask equipped with a stir bar and argon balloon was added $\mathbf{5 9}$ ( $2.00 \mathrm{~g}, 10.9 \mathrm{mmol}, 1 \mathrm{eq}$.) and DCM (45 mL) then cooled to $-78{ }^{\circ} \mathrm{C}$. A solution of 60 (0.945 g, $10.9 \mathrm{mmol}, 1$ eq.) and $\mathrm{Et}_{3} \mathrm{~N}$ (1.51 mL, $10.9 \mathrm{mmol}, 1$ eq.) in $\mathrm{DCM}(5 \mathrm{~mL})$ was added dropwise over 5 minutes. The reaction mixture stirred at $-78{ }^{\circ} \mathrm{C}$ for 1 hour then warmed to $-30{ }^{\circ} \mathrm{C}$ over 30 minutes then quenched with saturated aqueous ammonium chloride $(70 \mathrm{~mL})$. The aqueous layer was extracted with DCM (4x75 mL), combined organic layers were dried over $\mathrm{Na}_{2} \mathrm{SO}_{4}$, filtered and concentrated to give 61 ( $2.54 \mathrm{~g}, 10.8 \mathrm{mmol}, 99 \%$ yield) as a white solid that was suitably pure by HPLC and NMR to be used in the next step (contaminated with $\mathrm{Et}_{3} \mathrm{~N}$ ). $\mathrm{TLC}_{\mathrm{B}} \mathrm{R}_{f}=0.50$ (hexanes/EtOAc, 20\% EtOAc, UV). ${ }^{1} \mathrm{H}$ NMR: $\left(500 \mathrm{MHz}, \mathrm{CDCl}_{3}\right) \delta 3.87$ (dd, J 5.7, $4.1 \mathrm{~Hz}, 2 \mathrm{H}$ ), 3.74 (dd, J 5.7, 4.1 $\mathrm{Hz}, 2 \mathrm{H})$ ppm. ${ }^{13} \mathrm{C}$ NMR: $\left(126 \mathrm{MHz}, \mathrm{CDCl}_{3}\right) \delta 170.41,164.08,66.38,44.47$ ppm.

*Spectroscopic data are in accordance with the literature. ${ }^{45}$

\section{4,6-Dichloro-2-(methylsulfonyl)pyrimidine (62)}<smiles>CSc1nc(Cl)cc(Cl)n1</smiles>

24

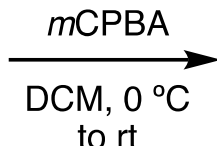

(quant.)<smiles>COSc1nc(Cl)cc(Cl)n1</smiles>

62

In a $200 \mathrm{~mL}$ round-bottomed flask equipped with a stir bar was added 24 (1.95 g, $10 \mathrm{mmol}, 1$ eq.) and DCM $(100 \mathrm{~mL})$ then cooled to $0{ }^{\circ} \mathrm{C}$. Once cool, mCPBA (4.6 g, $20 \mathrm{mmol}, 2$ eq.) was added portionwise, continued to stir at $0{ }^{\circ} \mathrm{C}$ for 15 minutes then warmed to room temperature where it stirred for 15 hours. The reaction was quenched with saturated aqueous $\mathrm{Na}_{2} \mathrm{~S}_{2} \mathrm{O}_{3}(30 \mathrm{~mL})$. The organic layer was washed with saturated aqueous $\mathrm{NaHCO}_{3}(3 \times 30 \mathrm{~mL})$, dried over $\mathrm{Na}_{2} \mathrm{SO}_{4}$, filtered and concentrated to provide $62(2.27 \mathrm{~g}, 10 \mathrm{mmol}$, quantitative yield) as a white solid. TLC: $R_{f}=0.63\left(50 \%\right.$ EtOAc in hexanes, UV). ${ }^{1} \mathrm{H} N M R:\left(500 \mathrm{MHz}, \mathrm{CDCl}_{3}\right) \delta 7.62(\mathrm{~s}, 1 \mathrm{H})$, 3.38 (s, 3H) ppm. ${ }^{13} \mathrm{C}$ NMR: $\left(126 \mathrm{MHz}, \mathrm{CDCl}_{3}\right) \delta 166.01,163.89,124.50,39.17$ ppm.

*Spectroscopic data are in accordance with the literature. ${ }^{46}$

\section{4,6-Dichloro-2-(1-naphthyl)pyrimidine (65)}<smiles>Clc1cc(Cl)nc(I)n1</smiles>

63<smiles>O=Cc1cccc2ccccc12</smiles>

64

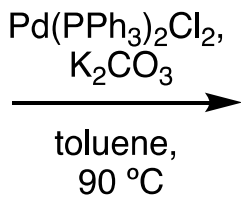

$(90 \%)$<smiles>O=S(=O)(O)c1nc(Cl)cc(Cl)n1</smiles> 
In a septum-capped $50 \mathrm{~mL}$ round-bottomed flask equipped with a stir bar and argon balloon was added $63^{47}$ (0.521 g, 1.89 mmol, 1 eq.), 64 (0.326g, 1.89 mmol, 1 eq.), $\mathrm{K}_{2} \mathrm{CO}_{3}\left(0.524 \mathrm{~g}, 3.79 \mathrm{mmol}, 2\right.$ eq.) and $\mathrm{Pd}\left(\mathrm{PPh}_{3}\right)_{2} \mathrm{Cl}_{2}$ ( $0.067 \mathrm{~g}, 0.095 \mathrm{mmol}, 0.05$ eq.). Toluene $(19 \mathrm{~mL})$ was added and the reaction mixture degassed using a flow of argon for 5 minutes. The reaction was heated $90^{\circ} \mathrm{C}$ for 3 hours then cooled to room temperature. Water (20 $\mathrm{mL}$ ) was added and the aqueous layer extracted with EtOAc $(3 \times 25 \mathrm{~mL})$, combined organic layers were dried over $\mathrm{Na}_{2} \mathrm{SO}_{4}$, filtered and concentrated. Further purification using silica gel column chromatography using hexanes/EtOAc ( $0 \%$ to $10 \%$ EtOAc gradient) provided $65(0.469 \mathrm{~g}, 1.70 \mathrm{mmol}, 90 \%$ yield) as a beige solid.

TLC: $R_{f}=0.74\left(10 \%\right.$ EtOAc in hexanes, UV). ${ }^{1} \mathrm{H}$ NMR: $\left(500 \mathrm{MHz}, \mathrm{CDCl}_{3}\right) \delta 8.79(\mathrm{~d}, J 8.6 \mathrm{~Hz}, 1 \mathrm{H}), 8.23$ (dd, J 7.2, $1.3 \mathrm{~Hz}, 1 \mathrm{H}), 8.02(\mathrm{~d}, J 8.3 \mathrm{~Hz}, 1 \mathrm{H}), 7.92(\mathrm{~d}, J 6.7 \mathrm{~Hz}, 1 \mathrm{H}), 7.64-7.52(\mathrm{~m}, 3 \mathrm{H}), 7.40(\mathrm{~s}, 1 \mathrm{H}) \mathrm{ppm} .{ }^{13} \mathrm{C}$ NMR: $(126$ $\left.\mathrm{MHz}_{1} \mathrm{CDCl}_{3}\right) \delta 167.74,161.77,134.09,132.62,132.29,130.79,130.74,128.73,127.61,126.23,125.28,125.06$, 118.70 ppm. HRMS: Calc'd for $\mathrm{C}_{14} \mathrm{H}_{9} \mathrm{Cl}_{2} \mathrm{~N}_{2}\left[\mathrm{M}+\mathrm{H}^{+}\right]$275.0137; found 275.0141.

\section{2,6-Dichloro-4-methylsulfonylpyridine (68)}<smiles>Clc1cc(Cl)nc(Cl)c1</smiles>

66

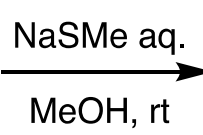

$(87 \%)$<smiles>Cc1cc(S(C)(C)C)cc(Cl)n1</smiles>

67

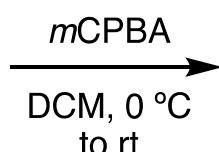

$(96 \%)$<smiles>COc1cc(Cl)nc(Cl)c1</smiles>

68

In a septum capped $30 \mathrm{~mL}$ vial equipped with a stir bar and an argon balloon was added 66 (1.0 g, $5.5 \mathrm{mmol}, 1$ eq.) and $\mathrm{MeOH}(9.2 \mathrm{~mL})$. An aqueous solution of NaSMe $(2.93 \mathrm{~mL}, 8.77 \mathrm{mmol}, 21 \% \mathrm{wt})$ was added and the argon balloon was removed. The resulting reaction mixture stirred at room temperature for 10 hours. Water $(4 \mathrm{~mL})$ was added and the reaction stirred for 5 minutes at which time a white precipitate was formed and collected by filtration. The collected solid was dried to give $67(0.930 \mathrm{~g}, 4.79 \mathrm{mmol}, 87 \%$ yield) as a white solid that was used in the next step without further purification or characterization.

In a $30 \mathrm{~mL}$ septum capped vial equipped with a stir bar was added 67 (0.810 g, $4.17 \mathrm{mmol}, 1$ eq.) and DCM (14 $\mathrm{mL}$ ) then cooled to $0^{\circ} \mathrm{C}$. $m$ CPBA $(1.92 \mathrm{~g}, 8.35 \mathrm{mmol}, 75 \% \mathrm{wt})$ was added portionwise and the resulting reaction mixture stirred at $0{ }^{\circ} \mathrm{C}$ for 15 minutes before warming to room temperature where it stirred for 8 hours. The reaction mixture was filtered through a sintered glass funnel, dried over $\mathrm{MgSO}_{4}$, filtered and concentrated. Further purification by silica gel column chromatography using hexanes/EtOAc (0\% to $15 \%$ EtOAc gradient) provided $68\left(0.910 \mathrm{~g}, 4.03 \mathrm{mmol}, 96 \%\right.$ yield) as a white solid. TLC: $R_{f}=0.29$ (20\% EtOAc in hexanes, UV).${ }^{1} \mathrm{H}$ NMR: $\left(500 \mathrm{MHz}, \mathrm{CDCl}_{3}\right) \delta 7.76(\mathrm{~s}, 2 \mathrm{H}), 3.13$ (s, 3H) ppm. ${ }^{13} \mathrm{C} \mathrm{NMR:}\left(126 \mathrm{MHz}, \mathrm{CDCl}_{3}\right) \delta 152.99,152.47,120.23$, 43.90 ppm. HRMS: Calc'd for $\mathrm{C}_{6} \mathrm{H}_{6} \mathrm{Cl}_{2} \mathrm{NO}_{2} \mathrm{~S}\left[\mathrm{M}+\mathrm{H}^{+}\right] 225.9491$; found 225.9501.

\section{9-Benzyl-6-chloropurine (70)}<smiles>Clc1ncnc2[nH]cnc12</smiles>

69

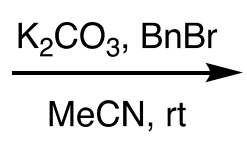

$(70 \%)$<smiles>Clc1ncnc2c1ncn2Cc1ccccc1</smiles>

70

In a septum capped $50 \mathrm{~mL}$ round-bottomed flask equipped with a stir bar and argon balloon was added 69 (1.0 $\mathrm{g}, 6.5 \mathrm{mmol}, 1$ eq.) followed by $\mathrm{K}_{2} \mathrm{CO}_{3}(1.78 \mathrm{~g}, 12.9 \mathrm{mmol}, 2$ eq.) and MeCN (26 mL). Benzyl bromide (BnBr) $(1.32 \mathrm{~g}, 0.922 \mathrm{~mL}, 7.36 \mathrm{mmol}, 1.2 \mathrm{eq}$.) was added dropwise to the stirring reaction mixture at room temperature. The reaction continued to stir at room temperature for 42 hours at which time the solvent was removed under reduced pressure and the crude oil was taken up in DCM (60 mL). A solution of saturated 
aqueous $\mathrm{NH}_{4} \mathrm{Cl}(50 \mathrm{~mL})$ was added and the aqueous layer extracted with $\mathrm{DCM}(4 \times 50 \mathrm{~mL})$. The organic layer was washed with a brine solution $\left(35 \mathrm{~mL}\right.$ ), dried over $\mathrm{Na}_{2} \mathrm{SO}_{4}$, filtered and concentrated. Further purification by silica gel column chromatography using hexanes/EtOAc (0\% to 40\% EtOAc gradient) provided 70 (1.1 g, 4.5 mmol, $70 \%$ yield) as a light-yellow solid. TLC: $R_{f}=0.39$ (50\% EtOAc in hexanes, UV). ${ }^{1} \mathrm{H}$ NMR: $\left(500 \mathrm{MHz} \mathrm{CDCl}_{3}\right)$ $\delta 8.79(\mathrm{~s}, 1 \mathrm{H}), 8.09(\mathrm{~s}, 1 \mathrm{H}), 7.38-7.30(\mathrm{~m}, 5 \mathrm{H}), 5.46(\mathrm{~s}, 2 \mathrm{H})$. NMR sample contained residual solvent.

*Spectroscopic data is in accordance with the literature. ${ }^{48}$

Phosphonate nucleophile scope

General phosphonate $S_{N} A r$ procedures
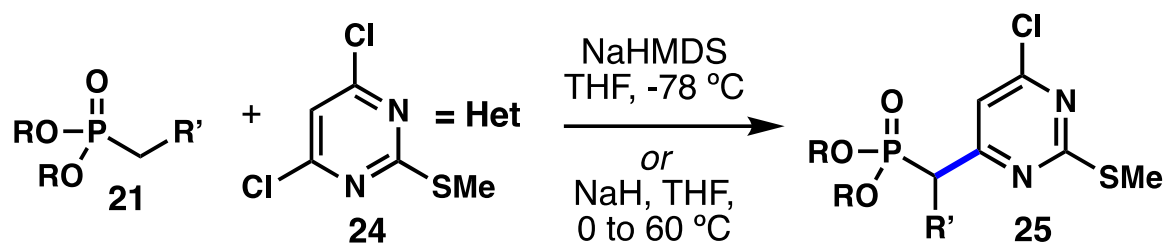

General Procedure 1 (GP-1) with NaHMDS. In a 2-dram septum capped reaction vial equipped with a stir bar and argon balloon was added phosphonates of a general structure $\mathbf{2 4}(0.275 \mathrm{mmol}, 1.1 \mathrm{eq}$.) and pyrimidine 24 $\left(0.250 \mathrm{mmol}, 1\right.$ eq.) along with THF $(2.5 \mathrm{~mL}, 0.1 \mathrm{M})$. The solution was cooled to $-78{ }^{\circ} \mathrm{C}$ and NaHMDS $(0.275 \mathrm{~mL}$, $0.550 \mathrm{mmol}, 2.2$ eq., $2 \mathrm{M}$ in THF) was added. The reactions were monitored at $-78{ }^{\circ} \mathrm{C}$ and warmed to room temperature when needed (see reaction times below). Once full consumption or no further consumption was observed (monitored by TLC and LC/MS), the reactions were quenched with saturated aqueous $\mathrm{NH}_{4} \mathrm{Cl}(8 \mathrm{~mL})$ and water $(5 \mathrm{~mL})$. The aqueous layer was extracted with EtOAc or DCM (15 mL x 4), dried over $\mathrm{Na}_{2} \mathrm{SO}_{4}$, filtered and concentrated. Further purification by silica gel column chromatography using hexanes/EtOAc or $\mathrm{DCM} / \mathrm{MeOH}$ provided the desired products.

General Procedure 2 (GP-2) with NaH. In a 2-dram septum capped reaction vial equipped with a stir bar and argon balloon was added phosphonates of a general structure to 24 (0.275 mmol, 1.1 eq.) and pyrimidine 24 (1 eq., $0.250 \mathrm{mmol}$ ) along with $\operatorname{THF}(2.5 \mathrm{~mL}, 0.1 \mathrm{M})$. The reaction mixtures were cooled to $0{ }^{\circ} \mathrm{C}$ then $\mathrm{NaH}(2.2$ eq., $60 \% \mathrm{wt}$ ) was added. The reactions were stirred at $0{ }^{\circ} \mathrm{C}$ for 5 minutes before warming to room temperature then heated to $60{ }^{\circ} \mathrm{C}$, if required (see below for reaction temperatures and times). Once full consumption or no further consumption was observed (monitored by TLC and LC/MS), the reactions were quenched with saturated aqueous $\mathrm{NH}_{4} \mathrm{Cl}(8 \mathrm{~mL})$ and water $(5 \mathrm{~mL})$. The aqueous layer was extracted with EtOAc or DCM (15 mL $\times 4$ ), dried over $\mathrm{Na}_{2} \mathrm{SO}_{4}$, filtered and concentrated. Further purification by silica gel column chromatography using hexanes/EtOAc, DCM/MeOH or EtOAc/MeOH provided the desired products.

\section{Dimethyl [6-chloro-2-(methylthio)pyrimidin-4-yl]methylphosphonate (26)}

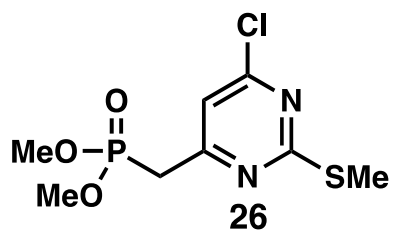

GP-1 was used with commercially available dimethyl methylphosphonate. After the addition of NaHMDS, the reaction stirred at $-78{ }^{\circ} \mathrm{C}$ for 1 hour then warmed to room temperature where it stirred for an additional 1 hour. Purified by silica gel column chromatography using hexanes/EtOAc (0\% to 60\% EtOAc gradient) to give 26 (55.0 mg, $0.195 \mathrm{mmol}$, 78\% yield) as a light-yellow oil. TLC: $\mathrm{R}_{f}=0.15$ (60\% EtOAc in hexanes, UV). ${ }^{1} \mathrm{H} N M R$ : 
$\left(500 \mathrm{MHz}, \mathrm{CDCl}_{3}\right) \delta 7.04(\mathrm{~d}, J 2.3 \mathrm{~Hz}, 1 \mathrm{H}), 3.78(\mathrm{~s}, 3 \mathrm{H}), 3.76(\mathrm{~s}, 3 \mathrm{H}), 3.28(\mathrm{~d}, J 22.4 \mathrm{~Hz}, 2 \mathrm{H}), 2.55(\mathrm{~s}, 3 \mathrm{H}) \mathrm{ppm} .{ }^{13} \mathrm{C}$

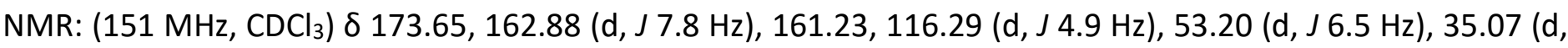
J $134.5 \mathrm{~Hz}$ ), 14.32 ppm. ${ }^{31} \mathrm{P}$ NMR: $\left(243 \mathrm{MHz}, \mathrm{CDCl}_{3}\right) \delta 24.71$ ppm. HRMS: Calc'd for $\mathrm{C}_{8} \mathrm{H}_{12} \mathrm{ClN}_{2} \mathrm{O}_{3} \mathrm{PSNa}\left[\mathrm{M}+\mathrm{Na}^{+}\right]$ 304.9887; found 304.9888 .

Diethyl [6-chloro-2-(methylthio)pyrimidin-4-yl]methylphosphonate (27)<smiles>CCOP(=O)(Cc1cc(Cl)nc(SC)n1)OCC</smiles>

GP-1 was used with commercially available diethyl methylphosphonate. After the addition of NaHMDS, the reaction stirred at $-78{ }^{\circ} \mathrm{C}$ for 1 hour then warmed to room temperature where it stirred for an additional 2 hours. Purified by silica gel column chromatography using hexanes/EtOAc (0\% to 60\% EtOAc gradient) to give 27 (54.0 mg, $0.174 \mathrm{mmol}, 69 \%$ yield) as a yellow oil. TLC: $R_{f}=0.18$ (60\% EtOAc in hexanes, UV). ${ }^{1} \mathrm{H}$ NMR: (500 $\mathrm{MHz}_{\mathrm{CDCl}}$ ) $\delta 7.05(\mathrm{~d}, J 2.3 \mathrm{~Hz}, 1 \mathrm{H}), 4.16-4.08(\mathrm{~m}, 4 \mathrm{H}), 3.27(\mathrm{~d}, J 22.4 \mathrm{~Hz}, 2 \mathrm{H}), 2.56(\mathrm{~s}, 3 \mathrm{H}), 1.31(\mathrm{t}, J 7.3 \mathrm{~Hz}$, 7H) ppm. ${ }^{13} \mathrm{C} \mathrm{NMR:}\left(126 \mathrm{MHz}, \mathrm{CDCl}_{3}\right) \delta 173.53(\mathrm{~d}, J 2.3 \mathrm{~Hz}), 163.25(\mathrm{~d}, J 7.7 \mathrm{~Hz}), 161.08(\mathrm{~d}, J 2.3 \mathrm{~Hz}), 116.33(\mathrm{~d}, J$ $4.5 \mathrm{~Hz}), 62.69$ (d, J $6.8 \mathrm{~Hz}$ ), 36.04 (d, J $133.9 \mathrm{~Hz}), 16.33$ (d, J $6.2 \mathrm{~Hz}) 14.26 \mathrm{ppm}$. HRMS: Calc'd for $\mathrm{C}_{20} \mathrm{H}_{21} \mathrm{ClN}_{2} \mathrm{O}_{3} \mathrm{PS}\left[\mathrm{M}+\mathrm{H}^{+}\right]$311.0381; found 311.0382.

Dibenzyl [6-chloro-2-(methylthio)pyrimidin-4-yl]methylphosphonate (28)<smiles></smiles>

GP-1 was used with previously synthesized 58. After the addition of NaHMDS, the reaction stirred at $-78{ }^{\circ} \mathrm{C}$ for 1 hour then warmed to room temperature where it stirred for an additional 2 hours. Purified by silica gel column chromatography using hexanes/EtOAc (0\% to 60\% EtOAc gradient) to give 28 (77.0 mg, $0.177 \mathrm{mmol}$, $71 \%$ yield) as a clear colorless oil. TLC: $\mathrm{R}_{\mathrm{f}}=0.34$ (40\% EtOAc in hexanes, UV). ${ }^{1} \mathrm{H}$ NMR: $\left(500 \mathrm{MHz}, \mathrm{CDCl}_{3}\right) \delta 7.38$ - $7.33(\mathrm{~m}, 6 \mathrm{H}), 7.32-7.27(\mathrm{~m}, 4 \mathrm{H}), 6.88(\mathrm{~d}, J 2.3 \mathrm{~Hz}, 1 \mathrm{H}), 5.08(\mathrm{dd}, J$ 11.7, $9.1 \mathrm{~Hz}, 2 \mathrm{H}), 4.98(\mathrm{dd}, J 11.7,8.6 \mathrm{~Hz}$, $2 \mathrm{H}$ ), 3.26 (d, J $22.6 \mathrm{~Hz}, 2 \mathrm{H}), 2.48(\mathrm{~s}, 3 \mathrm{H})$ ppm. ${ }^{13} \mathrm{C} \mathrm{NMR:}\left(126 \mathrm{MHz}, \mathrm{CDCl}_{3}\right) \delta 173.54$ (d, J $\left.1.8 \mathrm{~Hz}\right), 162.74$ (d, J 7.6 Hz), 161.03 (d, J $2.3 \mathrm{~Hz}$ ), 135.75 (d, J $6.0 \mathrm{~Hz}$ ), 128.68, 128.06, 116.35 (d, J 4.8 Hz), 68.12 (d, J $6.4 \mathrm{~Hz}$ ), 36.40 (d, J $134.3 \mathrm{~Hz}$ ), 14.22 ppm. ${ }^{31} \mathrm{P}$ NMR: $\left(243 \mathrm{MHz}, \mathrm{CDCl}_{3}\right) \delta 23.10$ ppm. HRMS: Calc'd for $\mathrm{C}_{20} \mathrm{H}_{21} \mathrm{ClN}_{2} \mathrm{O}_{3} \mathrm{PS}\left[\mathrm{M}+\mathrm{H}^{+}\right]$ 435.0694; found 435.0695.

Ethyl (2-diethoxyphosphonyl-2-[6-chloro-(2-methylthio)pyrimidin-4-yl]acetate (29)<smiles>CCOC(=O)C(c1cc(Cl)nc(SC)n1)P(=O)(O)OCC</smiles> 
GP-2 was used with commercially available ethyl 2-(diethoxyphosphoryl)acetate. After reaching room temperature, the reaction was heated to $60{ }^{\circ} \mathrm{C}$ for 15 hours. Purified by silica gel column chromatography using hexanes/EtOAc ( $0 \%$ to 50\% EtOAc gradient) to give $29(72.0 \mathrm{mg}, 0.188 \mathrm{mmol}, 75 \%$ yield) as a clear colorless oil. TLC: $\mathrm{R}_{\mathrm{f}}=0.22$ (40\% EtOAc in hexanes, UV). ${ }^{1} \mathrm{H}$ NMR: $\left(500 \mathrm{MHz}, \mathrm{CDCl}_{3}\right) \delta 7.45(\mathrm{~d}, J 2.1 \mathrm{~Hz}, 1 \mathrm{H}), 4.45$ $(\mathrm{d}, J 24.0 \mathrm{~Hz}, 1 \mathrm{H}), 4.29-4.21(\mathrm{~m}, 2 \mathrm{H}), 4.21-4.09(\mathrm{~m}, 4 \mathrm{H}), 2.54(\mathrm{~s}, 3 \mathrm{H}), 1.33-1.26(\mathrm{~m}, 9 \mathrm{H}) \mathrm{ppm} .{ }^{13} \mathrm{C}$ NMR: (126 $\left.\mathrm{MHz}_{,} \mathrm{CDCl}_{3}\right) \delta$ 173.19, 165.42 (d, J $\left.5.6 \mathrm{~Hz}\right), 161.94$ (d, J $\left.6.8 \mathrm{~Hz}\right), 161.17$ (d, J $\left.2.2 \mathrm{~Hz}\right), 116.50(\mathrm{~d}, J 3.2 \mathrm{~Hz}), 63.89$ (d, J $6.8 \mathrm{~Hz}$ ), 63.73 (d, J $6.7 \mathrm{~Hz}), 62.53,54.44$ (d, J $128.0 \mathrm{~Hz}$ ), 16.27 (d, J 3.4 Hz), 16.22 (d, J $3.3 \mathrm{~Hz}$ ), 14.26, 14.02 ppm. ${ }^{31} \mathrm{P}$ NMR: $\left(243 \mathrm{MHz}, \mathrm{CDCl}_{3}\right) \delta 15.30$ ppm. HRMS: Calc'd for $\mathrm{C}_{13} \mathrm{H}_{21} \mathrm{ClN}_{2} \mathrm{O}_{5} \mathrm{PS}\left[\mathrm{M}+\mathrm{H}^{+}\right]$383.0592; found 383.0591.

2-(Diethoxyphosphonyl)-2-[6-chloro-2-(methylthio)pyrimidin-4-ylidene]acetonitrile (30)

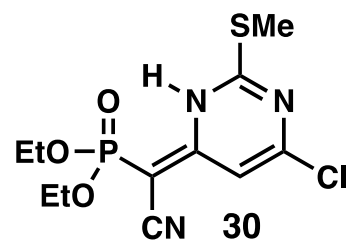

GP-2 was used with commercially available diethyl (cyanomethyl)phosphonate. After reaching room temperature, the reaction was heated to $60^{\circ} \mathrm{C}$ for 11 hours. Purified by silica gel column chromatography using hexanes/EtOAc (0\% to 40\% EtOAc gradient) to give $30(74.0 \mathrm{mg}, 0.220 \mathrm{mmol}, 88 \%$ yield) as a yellow crystalline solid. TLC: $\mathrm{R}_{f}=0.48\left(5 \% \mathrm{MeOH}\right.$ in DCM, UV). M.P. $=164{ }^{\circ} \mathrm{C} .{ }^{1} \mathrm{H} \mathrm{NMR:}\left(500 \mathrm{MHz}, \mathrm{CDCl}_{3}\right) \delta 13.31(\mathrm{~s}$, $1 \mathrm{H}), 6.78(\mathrm{t}, J 0.9 \mathrm{~Hz}, 1 \mathrm{H}), 4.19-4.09(\mathrm{~m}, 4 \mathrm{H}), 2.61(\mathrm{~s}, 3 \mathrm{H}), 1.38$ (td, J 7.1, 0.8 Hz, 6H) ppm. ${ }^{13} \mathrm{C} \mathrm{NMR:}(126 \mathrm{MHz}$, $\mathrm{CDCl}_{3}$ ) $\delta$ 162.78, 159.69 (d, J 8.2 Hz), 156.53 (d, J $3.1 \mathrm{~Hz}$ ), 117.08 (d, J 7.5 Hz), 107.87 (d, J 14.3 Hz), 63.44 (d, J $5.8 \mathrm{~Hz}$ ), 53.94 (d, J $206.8 \mathrm{~Hz}), 16.14$ (d, J $6.9 \mathrm{~Hz}), 13.75$ ppm. ${ }^{31} \mathrm{P}$ NMR: $\left(243 \mathrm{MHz}, \mathrm{CDCl}_{3}\right) \delta 20.25$ ppm. HRMS: Calc'd for $\mathrm{C}_{11} \mathrm{H}_{15} \mathrm{ClN}_{3} \mathrm{O}_{3} \mathrm{PSNa}\left[\mathrm{M}+\mathrm{Na}^{+}\right]$358.0152; found 358.0143 .

Diethyl 2-(4-nitrophenyl)-2-[6-chloro-2-(methylthio)pyrimidin-4-yl]methylphosphonate (31)

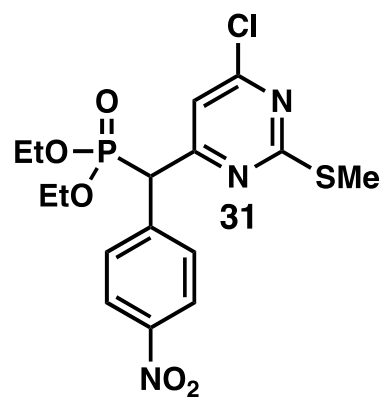

GP-2 was used with commercially available diethyl (4-nitrobenzyl)phosphonate. After reaching room temperature, the reaction continued stirring for 6 hours. Purified by silica gel column chromatography using hexanes/EtOAc (10\% to 35\% EtOAc gradient) to give $31(86.0 \mathrm{mg}, 0.199 \mathrm{mmol}, 80 \%$ yield) as a clear colorless oil. TLC: $\mathrm{R}_{\mathrm{f}}=0.26$ (40\% EtOAc in hexanes, UV). ${ }^{1} \mathrm{H}$ NMR: $\left(500 \mathrm{MHz}, \mathrm{CDCl}_{3}\right) \delta 8.21(\mathrm{~d}, J 8.2 \mathrm{~Hz}, 2 \mathrm{H}), 7.76$ (dd, J 8.9, $2.0 \mathrm{~Hz}, 2 \mathrm{H}), 7.22(\mathrm{~d}, J 1.5 \mathrm{~Hz}, 1 \mathrm{H}), 4.60(\mathrm{~d}, J 24.2 \mathrm{~Hz}, 1 \mathrm{H}), 4.15-3.91(\mathrm{~m}, 4 \mathrm{H}), 2.55(\mathrm{~s}, 3 \mathrm{H}), 1.24(\mathrm{t}, J 7.1 \mathrm{~Hz}$, 3H), 1.18 (t, J $7.0 \mathrm{~Hz}, 3 \mathrm{H}) \mathrm{ppm} .{ }^{13} \mathrm{C}$ NMR: $\left(126 \mathrm{MHz}, \mathrm{CDCl}_{3}\right) \delta 173.93,165.14$ (d, J 4.9 Hz), 161.57, 147.61 (d, J $2.8 \mathrm{~Hz}$ ), 140.78 (d, J $6.8 \mathrm{~Hz}$ ), 130.89 (d, J $6.9 \mathrm{~Hz}$ ), 123.75 (d, J 2.2 Hz), 116.00 (d, J $5.3 \mathrm{~Hz}), 63.74$ (d, J $6.9 \mathrm{~Hz}$ ), 63.34 (d, J $7.2 \mathrm{~Hz}), 53.05$ (d, J $136.3 \mathrm{~Hz}), 16.30$ (d, J $5.7 \mathrm{~Hz}) 14.37$ ppm. ${ }^{31} \mathrm{P} \mathrm{NMR:}\left(243 \mathrm{MHz}, \mathrm{CDCl}_{3}\right) \delta 19.59$ ppm. HRMS: Calc'd for $\mathrm{C}_{16} \mathrm{H}_{20} \mathrm{ClN}_{3} \mathrm{O}_{5} \mathrm{PS}\left[\mathrm{M}+\mathrm{H}^{+}\right]$432.0544; found 432.0542 . 


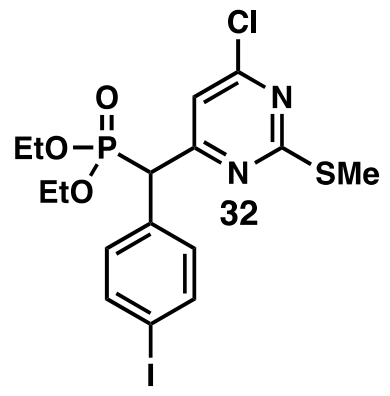

GP-1 was used with commercially available diethyl (4-iodobenzyl)phosphonate. After the addition of NaHMDS, the reaction stirred at $-78{ }^{\circ} \mathrm{C}$ for 1 hour. The dry-ice bath was removed and the reaction quenched after 10 minutes. Purified by silica gel column chromatography using hexanes/EtOAc ( $0 \%$ to $20 \%$ EtOAc gradient) to give 32 (0.105 g, $0.205 \mathrm{mmol}, 82 \%$ yield) as a clear colorless oil. TLC: $R_{f}=0.40$ (40\% EtOAc in hexanes, UV). ${ }^{1} \mathrm{H}$ NMR: $\left(500 \mathrm{MHz}, \mathrm{CDCl}_{3}\right) \delta 7.68(\mathrm{dd}, J 8.7,0.8 \mathrm{~Hz}, 2 \mathrm{H}), 7.31(\mathrm{dd}, J 8.5,2.0 \mathrm{~Hz}, 2 \mathrm{H}), 7.20(\mathrm{~d}, J 1.5 \mathrm{~Hz}, 1 \mathrm{H}), 4.43(\mathrm{~d}, J$ $24.1 \mathrm{~Hz}, 1 \mathrm{H}), 4.13-3.88(\mathrm{~m}, 4 \mathrm{H}), 2.55(\mathrm{~s}, 3 \mathrm{H}), 1.23(\mathrm{t}, J 6.8 \mathrm{~Hz}, 3 \mathrm{H}), 1.16(\mathrm{t}, J 6.8 \mathrm{~Hz}, 3 \mathrm{H}) \mathrm{ppm} .{ }^{13} \mathrm{C} \mathrm{NMR}:(126$

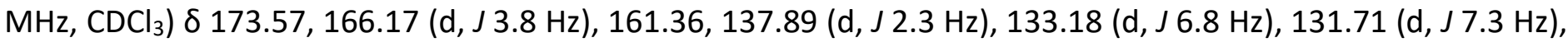
115.85 (d, J $5.1 \mathrm{~Hz}$ ), 93.97 (d, J $3.2 \mathrm{~Hz}), 63.59$ (d, J $6.8 \mathrm{~Hz}), 63.04$ (d, J $7.1 \mathrm{~Hz}$ ), 52.81 (d, J $137.1 \mathrm{~Hz}$ ), 16.32 (d, J $1.7 \mathrm{~Hz}$ ), 16.28 (d, J $1.6 \mathrm{~Hz}$ ), 14.36 ppm. ${ }^{31} \mathrm{P}$ NMR: (243 MHz, CDCl 3 ) $\delta 20.51 \mathrm{ppm}$. HRMS: Calc'd for $\mathrm{C}_{16} \mathrm{H}_{20} \mathrm{ClIN}{ }_{2} \mathrm{O}_{3} \mathrm{PS}\left[\mathrm{M}+\mathrm{H}^{+}\right]$512.9660; found 512.9657.

Diethyl 2-(3-bromophenyl)-2-[6-chloro-2-(methylthio)pyrimidin-4-yl]methylphosphonate (33)<smiles>CCOP(=O)(OCC)C(c1cccc(Br)c1)c1cc(Cl)nc(SC)n1</smiles>

GP-1 was used with commercially available diethyl (3-bromobenzyl)phosphonate. After the addition of NaHMDS, the reaction stirred at $-78{ }^{\circ} \mathrm{C}$ for 1 hour then warmed to room temperature where it stirred for an additional 1 hour. Purified by silica gel column chromatography using hexanes/EtOAc (0\% to 20\% EtOAc gradient) to give 33 (99.0 $\mathrm{mg}, 0.212 \mathrm{mmol}, 85 \%$ yield) as a clear colorless oil.

TLC: $R_{f}=0.45$ (40\% EtOAc in hexanes, UV). ${ }^{1} \mathrm{H}$ NMR: $\left(500 \mathrm{MHz}, \mathrm{CDCl}_{3}\right) \delta 7.73(\mathrm{dd}, J 1.9 \mathrm{~Hz}, 1 \mathrm{H}), 7.53-7.47(\mathrm{~m}$, 1H), $7.47-7.41(\mathrm{~m}, 1 \mathrm{H}), 7.23(\mathrm{~d}, J 7.9 \mathrm{~Hz}, 1 \mathrm{H}), 7.20(\mathrm{~d}, J 1.7 \mathrm{~Hz}, 1 \mathrm{H}), 4.45(\mathrm{~d}, J 24.2 \mathrm{~Hz}, 1 \mathrm{H}), 4.09-3.91(\mathrm{~m}, 4 \mathrm{H})$, $2.56(\mathrm{~s}, 3 \mathrm{H}), 1.23(\mathrm{t}, J 7.1 \mathrm{~Hz}, 3 \mathrm{H}), 1.16(\mathrm{t}, J 7.1 \mathrm{~Hz}, 3 \mathrm{H})$ ppm. ${ }^{13} \mathrm{C}$ NMR: $\left(126 \mathrm{MHz}, \mathrm{CDCl}_{3}\right) \delta$ 173.61, 165.94 (d, J $4.1 \mathrm{~Hz}), 161.34,135.53$ (d, J $6.8 \mathrm{~Hz}$ ), 132.94 (d, J 7.3 Hz), 131.19 (d, J 2.7 Hz), 130.20 (d, J 2.3 Hz), 122.60 (d, J $1.8 \mathrm{~Hz}$ ), 115.95 (d, J $5.0 \mathrm{~Hz}$ ), 63.62 (d, J $7.3 \mathrm{~Hz}$ ), 63.09 (d, J $6.8 \mathrm{~Hz}$ ), 52.84 (d, J $137.1 \mathrm{~Hz}), 16.38$ - 16.17 (m) 14.38 ppm. ${ }^{31}$ P NMR: $\left(243 \mathrm{MHz}, \mathrm{CDCl}_{3}\right) \delta 20.42$ ppm. HRMS: Calc'd for $\mathrm{C}_{16} \mathrm{H}_{20} \mathrm{BrClN}_{2} \mathrm{O}_{3} \mathrm{PS}\left[\mathrm{M}+\mathrm{H}^{+}\right]$464.9799; found 464.9798 . 


\section{Diethyl 2-(4-chlorophenyl)-2-[6-chloro-2-(methylthio)pyrimidin-4-yl]methylphosphonate (34)}<smiles>CCOP(=O)(OCC)C(c1ccc(Cl)cc1)c1cc(Cl)nc(SC)n1</smiles>

GP-1 was used with commercially available diethyl (4-chlorobenzyl)phosphonate. After the addition of NaHMDS, the reaction stirred at $-78{ }^{\circ} \mathrm{C}$ for 1 hour then warmed to room temperature where it stirred for an additional 2 hours. Purified by silica gel column chromatography using hexanes/EtOAc (0\% to 40\% EtOAc gradient) to give $34\left(96.0 \mathrm{mg}, 0.227 \mathrm{mmol}, 91 \%\right.$ yield) as a clear colorless oil. TLC: $R_{f}=0.26(40 \%$ EtOAc in hexanes, UV). ${ }^{1} \mathrm{H} N M R:\left(500 \mathrm{MHz}, \mathrm{CDCl}_{3}\right) \delta 7.50$ (dd, J 8.6, $\left.2.0 \mathrm{~Hz}, 2 \mathrm{H}\right), 7.32(\mathrm{~d}, J 8.5 \mathrm{~Hz}, 2 \mathrm{H}), 7.20(\mathrm{~d}, J 1.5 \mathrm{~Hz}$, $1 \mathrm{H}), 4.47(\mathrm{~d}, J 24.1 \mathrm{~Hz}, 1 \mathrm{H}), 4.14-3.85(\mathrm{~m}, 4 \mathrm{H}), 2.54(\mathrm{~s}, 3 \mathrm{H}), 1.22(\mathrm{t}, J 7.1 \mathrm{~Hz}, 3 \mathrm{H}), 1.15(\mathrm{t}, J 7.1 \mathrm{~Hz}, 3 \mathrm{H}) \mathrm{ppm}$.

${ }^{13} \mathrm{C}$ NMR: $\left(126 \mathrm{MHz}, \mathrm{CDCl}_{3}\right) \delta$ 173.56, $166.27(\mathrm{~d}, J 3.7 \mathrm{~Hz}), 161.34,134.17$ (d, J $\left.2.9 \mathrm{~Hz}\right), 131.95(\mathrm{~d}, J 6.7 \mathrm{~Hz})$, 131.17 (d, J $7.4 \mathrm{~Hz}$ ), 128.94 (d, J $1.8 \mathrm{~Hz}$ ), 115.85 (d, J $5.2 \mathrm{~Hz}), 63.57$ (d, J $6.9 \mathrm{~Hz}), 63.02$ (d, J $7.2 \mathrm{~Hz}$ ), 52.60 (d, J $137.1 \mathrm{~Hz}), 16.31$ (d, J $2.4 \mathrm{~Hz}), 16.26(\mathrm{~d}, J 2.2 \mathrm{~Hz}), 14.34$ ppm. ${ }^{31} \mathrm{P}$ NMR: $\left(243 \mathrm{MHz}, \mathrm{CDCl}_{3}\right) \delta 20.68 \mathrm{ppm}$. HRMS: Calc'd for $\mathrm{C}_{16} \mathrm{H}_{20} \mathrm{Cl}_{2} \mathrm{~N}_{2} \mathrm{O}_{3} \mathrm{PS}\left[\mathrm{M}+\mathrm{Na}^{+}\right]$421.0304; found 421.0296 .

Diethyl 2-(4-fluorophenyl)-2-[6-chloro-2-(methylthio)pyrimidin-4-yl]methylphosphonate (35)<smiles>CCOP(=O)(OCC)C(c1ccc(F)cc1)c1cc(Cl)nc(SC)n1</smiles>

GP-1 was used with commercially available diethyl (4-fluorobenzyl)phosphonate. After the addition of NaHMDS, the reaction stirred at $-78{ }^{\circ} \mathrm{C}$ for 1 hour then warmed to room temperature where it stirred for an additional 1 hour. Purified by silica gel column chromatography using hexanes/EtOAc (0\% to 40\% EtOAc gradient) to give $35\left(84.0 \mathrm{mg}, 0.207 \mathrm{mmol}, 83 \%\right.$ yield) as a clear colorless oil. TLC: $R_{f}=0.32(40 \%$ EtOAc in hexanes, UV). ${ }^{1} \mathrm{H}$ NMR: (500 MHz, $\left.\mathrm{CDCl}_{3}\right) \delta 7.57-7.51(\mathrm{~m}, 2 \mathrm{H}), 7.21(\mathrm{~d}, J 1.6 \mathrm{~Hz}, 1 \mathrm{H}), 7.07-7.01(\mathrm{~m}, 2 \mathrm{H}), 4.49$ $(\mathrm{d}, J 24.2 \mathrm{~Hz}, 1 \mathrm{H}), 4.11-3.85(\mathrm{~m}, 4 \mathrm{H}), 2.55(\mathrm{~s}, 3 \mathrm{H}), 1.23(\mathrm{t}, J 7.3 \mathrm{~Hz}, 3 \mathrm{H}), 1.14(\mathrm{t}, J 7.4 \mathrm{~Hz}, 3 \mathrm{H}) \mathrm{ppm} .{ }^{13} \mathrm{C} \mathrm{NMR}$ :

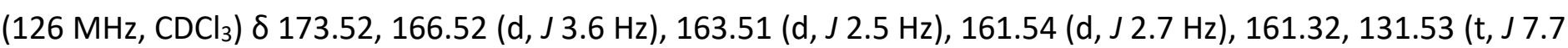
$\mathrm{Hz}), 129.19$ (dd, J 6.7, 3.5 Hz), 115.84 (d, J $2.7 \mathrm{~Hz}$ ), 115.81, 115.65, 63.52 (d, J $6.9 \mathrm{~Hz}), 62.96$ (d, J 7.2 Hz), 52.44 (d, J $137.4 \mathrm{~Hz}$ ), 16.30 (d, J $5.2 \mathrm{~Hz}), 16.26$ (d, J $5.0 \mathrm{~Hz}), 14.34$ ppm. ${ }^{19} \mathrm{~F} \mathrm{NMR:}\left(471 \mathrm{MHz}, \mathrm{CDCl}_{3}\right) \delta-113.88$ (d, J 3.5 $\mathrm{Hz}$ ) ppm. ${ }^{31} \mathrm{P}$ NMR: $\left(243 \mathrm{MHz}, \mathrm{CDCl}_{3}\right) \delta 21.02$ ppm. HRMS: Calc'd for $\mathrm{C}_{16} \mathrm{H}_{20} \mathrm{ClFN}_{2} \mathrm{O}_{3} \mathrm{PS}\left[\mathrm{M}+\mathrm{H}^{+}\right]$405.0599; found 405.0598. 


\section{Phosphonate SNAr Electrophile Scope-}

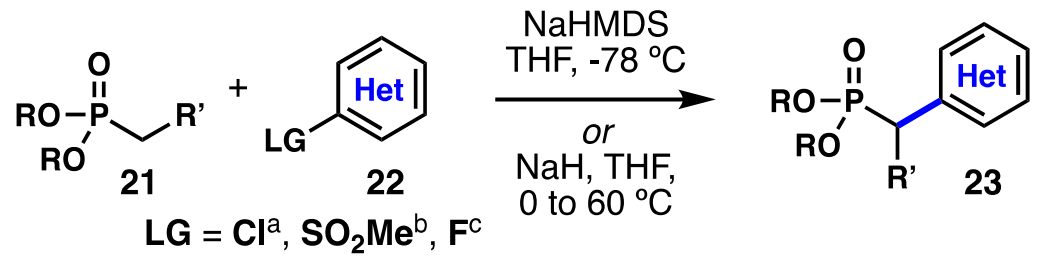

*GP-1 and GP-2 were used. The phosphonates and heterocyclic electrophiles used are described below.

Dimethyl (4-chloro-6-morpholino-1,3,5-triazinyl-2-yl)methylphosphonate (36)

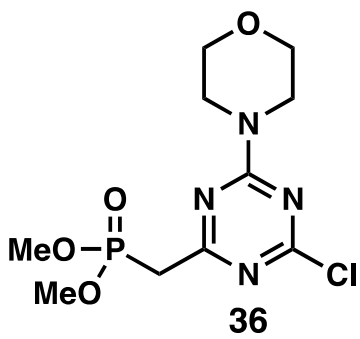

GP-1 was used with previously synthesized $\mathbf{6 1}$ and commercially available dimethyl methylphosphonate. After the addition of NaHMDS, the reaction stirred at $-78{ }^{\circ} \mathrm{C}$ for 1 hour then warmed to room temperature where it stirred for an additional 1 hour. Purified by silica gel column chromatography using DCM/MeOH $(0 \%$ to $5 \%$ $\mathrm{MeOH}$ gradient) to give $36\left(73.0 \mathrm{mg}, 0.226 \mathrm{mmol}, 90 \%\right.$ yield) as a light-yellow oil. TLC: $\mathrm{R}_{\mathrm{f}}=0.44(5 \% \mathrm{MeOH}$ in DCM, UV). ${ }^{1} \mathrm{H}$ NMR: $\left(500 \mathrm{MHz}, \mathrm{CDCl}_{3}\right) \delta 3.92-3.88(\mathrm{~m}, 2 \mathrm{H}), 3.86-3.83(\mathrm{~m}, 2 \mathrm{H}), 3.82(\mathrm{~s}, 3 \mathrm{H}), 3.79(\mathrm{~s}, 3 \mathrm{H}), 3.74$ - $3.72(\mathrm{~m}, 4 \mathrm{H}), 3.31(\mathrm{~s}, 1 \mathrm{H}), 3.26(\mathrm{~s}, 1 \mathrm{H}) \mathrm{ppm} .{ }^{13} \mathrm{C} \mathrm{NMR}:\left(126 \mathrm{MHz}, \mathrm{CDCl}_{3}\right) \delta 172.26$ (d, J 7.1 Hz), 170.49, 164.27, 66.45, 53.18 (d, J $6.4 \mathrm{~Hz}$ ), 44.14, 43.92, 36.80 (d, J 133.9 Hz) ppm. ${ }^{31} \mathrm{p}$ NMR: $\left(243 \mathrm{MHz}, \mathrm{CDCl}_{3}\right) \delta 24.65$ ppm. HRMS: Calc'd for $\mathrm{C}_{10} \mathrm{H}_{16} \mathrm{ClN}_{4} \mathrm{O}_{4} \mathrm{PNa}\left[\mathrm{M}+\mathrm{Na}^{+}\right]$345.0490; found 345.0489.

Dimethyl (4,6-dimethoxypyrimidin-2-yl)methylphosphonate (37)

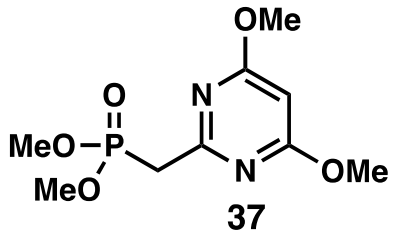

GP-1 was used with commercially available diethyl (4-chlorobenzyl)phosphonate and 2-chloro-4,6dimethoxypyrimidine. After the addition of NaHMDS, the reaction stirred at $-78{ }^{\circ} \mathrm{C}$ for 1 hour then warmed to room temperature where it stirred for an additional 15 hours. Purified by silica gel column chromatography using $\mathrm{DCM} / \mathrm{MeOH}(0 \%$ to $10 \% \mathrm{MeOH}$ gradient) to give $37(37.0 \mathrm{mg}, 0.141 \mathrm{mmol}, 56 \%$ yield) as a light-yellow oil. TLC: $R_{f}=0.28$ (5\% MeOH in DCM, UV). ${ }^{1} \mathrm{H} N M R:\left(500 \mathrm{MHz}, \mathrm{CDCl}_{3}\right) \delta 5.91(\mathrm{~d}, J 1.8 \mathrm{~Hz}, 1 \mathrm{H}), 3.93(\mathrm{~s}, 6 \mathrm{H}), 3.81$ (s, 3H), 3.79 (s, 3H), 3.43 (d, J $\left.22.2 \mathrm{~Hz}, 2 \mathrm{H}) \mathrm{ppm} .{ }^{13} \mathrm{C} \mathrm{NMR:} \mathrm{(126} \mathrm{MHz,} \mathrm{CDCl}\right) \delta 171.46$ (d, J $\left.2.0 \mathrm{~Hz}\right), 161.86$ (d, J $8.4 \mathrm{~Hz}$ ), 87.87 (d, J $2.8 \mathrm{~Hz}), 54.15,52.89$ (d, J $6.2 \mathrm{~Hz}), 36.75$ (d, J $133.8 \mathrm{~Hz})$ ppm. ${ }^{31} \mathrm{P} N M R:\left(243 \mathrm{MHz}, \mathrm{CDCl}_{3}\right) \delta$ 26.66 ppm. HRMS: Calc'd for $\mathrm{C}_{9} \mathrm{H}_{16} \mathrm{~N}_{2} \mathrm{O}_{5} \mathrm{P}\left[\mathrm{M}+\mathrm{H}^{+}\right]$263.0791; found 263.0789. 


\section{Dimethyl [6-chloro-2-(1-naphthyl)pyrimidin-4-yl]methylphosphonate (38)}<smiles>COP(=O)(Cc1cc(Cl)nc(-c2cccc3ccccc23)n1)OC</smiles>

GP-1 was used with commercially available dimethyl methylphosphonate and previously synthesized 65 (4,6dichloro-2-(naphthalen-1-yl)pyrimidine). After the addition of NaHMDS, the reaction stirred at $-78{ }^{\circ} \mathrm{C}$ for 1 hour then warmed to room temperature where it stirred for an additional 1 hour. Purified by silica gel column chromatography using $\mathrm{DCM} / \mathrm{MeOH}(0 \%$ to $2 \% \mathrm{MeOH}$ gradient) to give 38 (44.0 $\mathrm{mg}, 0.135 \mathrm{mmol}, 48 \%$ yield) as a golden oil. TLC: $R_{f}=0.25$ (80\% EtOAc in hexanes, UV). ${ }^{1} \mathrm{H}$ NMR: $\left(500 \mathrm{MHz}, \mathrm{CDCl}_{3}\right) \delta 8.72(\mathrm{dd}, J 8.7,1.2 \mathrm{~Hz}, 1 \mathrm{H})$, $8.13(\mathrm{dd}, J 7.2,1.4 \mathrm{~Hz}, 1 \mathrm{H}), 8.01-7.97(\mathrm{~m}, 1 \mathrm{H}), 7.93-7.90(\mathrm{~m}, 1 \mathrm{H}), 7.60-7.51(\mathrm{~m}, 3 \mathrm{H}), 7.40(\mathrm{~d}, J 2.3 \mathrm{~Hz}, 1 \mathrm{H})$, $3.83(\mathrm{~s}, 3 \mathrm{H}), 3.81(\mathrm{~s}, 3 \mathrm{H}), 3.49$ (d, J $22.4 \mathrm{~Hz}, 2 \mathrm{H})$ ppm. ${ }^{13} \mathrm{C}$ NMR: $\left(126 \mathrm{MHz}, \mathrm{CDCl}_{3}\right) \delta 167.48$ (d, J $\left.2.7 \mathrm{~Hz}\right), 163.00$ (d, J $8.2 \mathrm{~Hz}$ ), 161.65 (d, J $2.7 \mathrm{~Hz}$ ), 134.07 (d, J $6.8 \mathrm{~Hz}$ ), 131.42, 130.87, 130.08, 128.58, 127.11, 126.06, 125.62, 125.12, 121.00 (d, J $4.5 \mathrm{~Hz}$ ), 119.04 (d, J $5.0 \mathrm{~Hz}$ ), 53.22 (d, J $6.4 \mathrm{~Hz}$ ), 35.35 (d, J $134.4 \mathrm{~Hz}$ ) ppm. ${ }^{31}$ P NMR: (243 $\left.\mathrm{MHz}, \mathrm{CDCl}_{3}\right) \delta 24.98$ ppm. HRMS: Calc'd for $\mathrm{C}_{17} \mathrm{H}_{17} \mathrm{ClN}_{2} \mathrm{O}_{3} \mathrm{P}\left[\mathrm{M}+\mathrm{H}^{+}\right]$363.0660; found 363.0661.

Diethyl [4-chlorophenyl)-2-(4,6-dichloropyrimidin-2-yl]methylphosphonate (39)<smiles>CCOP(=O)(OCC)C(c1ccc(Cl)cc1)c1nc(Cl)cc(Cl)n1</smiles>

GP-1 was used with commercially available diethyl (4-chlorobenzyl)phosphonate and previously synthesized 62 (4,6-dichloro-2-(methylsulfonyl)pyrimidine). After the addition of NaHMDS, the reaction stirred at $-78{ }^{\circ} \mathrm{C}$ for 1 hour then warmed to room temperature where it stirred for an additional 20 minutes. Purified by silica gel column chromatography using hexanes/EtOAc (0\% to 40\% EtOAc gradient) to give 39 (72.0 mg, 0.175 mmol, 70\% yield) as a clear colorless oil. TLC: $R_{f}=0.22$ (40\% EtOAc in hexanes, UV). ${ }^{1} \mathrm{H} \mathrm{NMR:}\left(500 \mathrm{MHz} \mathrm{CDCl}_{3}\right)$

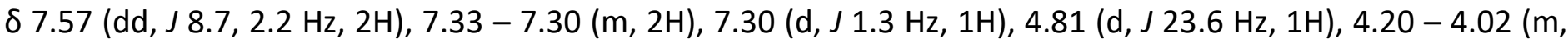
4H), $1.29-1.21(\mathrm{~m}, 6 \mathrm{H}) \mathrm{ppm} .{ }^{13} \mathrm{C} \mathrm{NMR}:\left(126 \mathrm{MHz}, \mathrm{CDCl}_{3}\right) \delta 167.01$ (d, J $\left.5.0 \mathrm{~Hz}\right), 162.05,134.05(\mathrm{~d}, J 3.4 \mathrm{~Hz})$, 131.68 (d, J $8.2 \mathrm{~Hz}), 131.31$ (d, J $6.5 \mathrm{~Hz}), 128.70$ (d, J $2.2 \mathrm{~Hz}), 119.80,63.98$ (d, J $6.7 \mathrm{~Hz}), 62.95$ (d, J $7.1 \mathrm{~Hz})$, 54.58 (d, J $136.8 \mathrm{~Hz}$ ), 16.37 (d, J $5.9 \mathrm{~Hz}), 16.27$ (d, J $6.0 \mathrm{~Hz}$ ) ppm. ${ }^{31} \mathrm{p}$ NMR: (243 MHz, CDCl $) \delta 19.52$ ppm. HRMS: Calc'd for $\mathrm{C}_{15} \mathrm{H}_{17} \mathrm{Cl}_{3} \mathrm{~N}_{2} \mathrm{O}_{3} \mathrm{P}\left[\mathrm{M}+\mathrm{H}^{+}\right]$409.0037; found 409.0035 . 


\section{Ethyl [2-diethoxyphosphonyl-2-(4,6-dichloropyrimidin-4-yl]acetate (40)}<smiles>CCOC(=O)C(c1nc(Cl)cc(Cl)n1)P(=O)(O)OCC</smiles>

GP-2 was used with commercially available ethyl 2-(diethoxyphosphoryl)acetateand previously synthesized 62 (4,6-dichloro-2-(methylsulfonyl)pyrimidine). After reaching room temperature, the reaction heated to $60{ }^{\circ} \mathrm{C}$ for 12 hours. Purified by silica gel column chromatography using hexanes/EtOAc (0\% to 40\% EtOAc gradient) to give 40 (69.0 mg, $0.186 \mathrm{mmol}, 74 \%$ yield) as a clear colorless oil that solidified upon standing. $T L C: R_{f}=0.42$ (60\% EtOAc in hexanes, UV). ${ }^{1} \mathrm{H}$ NMR: $\left(600 \mathrm{MHz}, \mathrm{CDCl}_{3}\right) \delta 7.33(\mathrm{~d}, J 1.2 \mathrm{~Hz}, 1 \mathrm{H}), 4.72(\mathrm{~d}, J 23.1 \mathrm{~Hz}, 1 \mathrm{H}), 4.43-$ $4.21(\mathrm{~m}, 6 \mathrm{H}), 1.38-1.31(\mathrm{~m}, 6 \mathrm{H}), 1.27(\mathrm{t}, J 7.1 \mathrm{~Hz}, 3 \mathrm{H})$ ppm. ${ }^{13} \mathrm{C}$ NMR: $\left(151 \mathrm{MHz}, \mathrm{CDCl}_{3}\right) \delta 165.18(\mathrm{~d}, J 5.5 \mathrm{~Hz})$, $163.63(\mathrm{~d}, J 6.3 \mathrm{~Hz}), 162.03,120.13,64.32(\mathrm{~d}, J 6.4 \mathrm{~Hz}), 63.58(\mathrm{~d}, J 6.5 \mathrm{~Hz}), 62.40,56.10(\mathrm{~d}, J 133.3 \mathrm{~Hz}), 16.34(\mathrm{t}$, J $7.4 \mathrm{~Hz}$ ), 14.01 ppm. ${ }^{31} \mathrm{P}$ NMR: (243 MHz, CDCl 3 ) $\delta 15.02$ ppm. HRMS: Calc'd for $\mathrm{C}_{12} \mathrm{H}_{18} \mathrm{Cl}_{2} \mathrm{~N}_{2} \mathrm{O}_{5} \mathrm{P}\left[\mathrm{M}^{\prime} \mathrm{H}^{+}\right]$ 371.0325; found 371.0322.

\section{Ethyl (2-diethoxyphosphonyl)-2-(9-benzylpyrimidin-6-yl)acetate (41)}

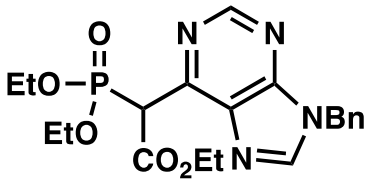

41

GP-2 was used with commercially available ethyl 2-(diethoxyphosphoryl)acetate and previously synthesized 70 (9-benzyl-6-chloro-9H-purine). After reaching room temperature, the reaction heated to $60{ }^{\circ} \mathrm{C}$ for 18 hours. Purified by silica gel column chromatography using DCM/MeOH (0\% to 5\% MeOH gradient) to give 41 (71.0 $\mathrm{mg}, 0.164 \mathrm{mmol}, 66 \%$ yield) as a clear colorless oil. TLC: $\mathrm{R}_{\mathrm{f}}=0.2(5 \% \mathrm{MeOH}$ in DCM, UV)

${ }^{1} \mathrm{H}$ NMR: $\left(500 \mathrm{MHz}, \mathrm{CDCl}_{3}\right) \delta 9.03(\mathrm{~s}, 1 \mathrm{H}), 8.03(\mathrm{~s}, 1 \mathrm{H}), 7.38-7.30(\mathrm{~m}, 5 \mathrm{H}), 5.43(\mathrm{~s}, 2 \mathrm{H}), 5.38(\mathrm{~d}, J 23.3 \mathrm{~Hz}, 1 \mathrm{H})$, $4.38-4.28(\mathrm{~m}, 2 \mathrm{H}), 4.27-4.19(\mathrm{~m}, 4 \mathrm{H}), 1.30-1.23(\mathrm{~m}, 9 \mathrm{H})$ ppm. ${ }^{13} \mathrm{C} \mathrm{NMR}:\left(126 \mathrm{MHz} \mathrm{CDCl}_{3}\right) \delta 165.72(\mathrm{~d}, J 4.6$ $\mathrm{Hz}), 152.53(\mathrm{~d}, J 2.1 \mathrm{~Hz}), 152.15$ (d, J $8.1 \mathrm{~Hz}), 151.59,144.53,134.86,132.90$ (d, J $6.4 \mathrm{~Hz}), 129.22,128.74$, 128.02, 63.71 (d, J $6.3 \mathrm{~Hz}$ ), 63.41 (d, J $6.4 \mathrm{~Hz}), 62.19,49.57$ (d, J $134.9 \mathrm{~Hz}$ ), 47.48, $16.44-16.20$ (m), 14.02 ppm. 31P NMR: (243 MHz, CDCl 3 ) $\delta$ 16.24. HRMS: Calc'd for $\mathrm{C}_{20} \mathrm{H}_{26} \mathrm{~N}_{4} \mathrm{O}_{5} \mathrm{P}\left[\mathrm{M}+\mathrm{H}^{+}\right]$433.1635; found 433.1634.

\section{Diethyl (4-fluorophenyl)(2-pyrimidinyl)methylphosphonate (42)}

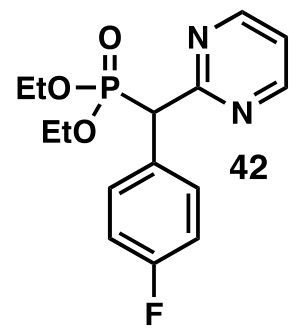

GP-1 was used with commercially available diethyl (4-fluorobenzyl)phosphonate and 2-chloropyrimidine. After the addition of NaHMDS, the reaction stirred at $-78{ }^{\circ} \mathrm{C}$ for 1 hour then warmed to room temperature where it 
stirred for an additional 15 hours. Purified by silica gel column chromatography using DCM/MeOH $(0 \%$ to $5 \%$ $\mathrm{MeOH}$ gradient) to give 42 (44.0 mg, $0.135 \mathrm{mmol}, 54 \%$ yield) as a yellow oil. TLC: $\mathrm{R}_{\mathrm{f}}=0.35$ (5\% MeOH in DCM, UV). ${ }^{1} \mathrm{H}$ NMR: $\left(600 \mathrm{MHz}, \mathrm{CDCl}_{3}\right) \delta 8.77(\mathrm{~d}, J 4.9 \mathrm{~Hz}, 2 \mathrm{H}), 7.66(\mathrm{ddq}, J 10.6,5.3,3.2 \mathrm{~Hz}, 2 \mathrm{H}), 7.23(\mathrm{td}, J 4.9,1.2 \mathrm{~Hz}$, 1H), $7.02(\mathrm{t}, J 8.6 \mathrm{~Hz}, 2 \mathrm{H}), 4.95(\mathrm{~d}, J 23.6 \mathrm{~Hz}, 1 \mathrm{H}), 4.14-3.96(\mathrm{~m}, 4 \mathrm{H}), 1.18(\mathrm{t}, J 7.1 \mathrm{~Hz}, 6 \mathrm{H}) \mathrm{ppm} .{ }^{13} \mathrm{C} N \mathrm{NMR}:(151$ $\left.\mathrm{MHz}_{\mathrm{CDCl}}\right) \delta 166.13,161.59,157.45,131.73(\mathrm{~d}, J 7.6 \mathrm{~Hz}), 129.86(\mathrm{~d}, J 4.6 \mathrm{~Hz}), 119.46,115.37(\mathrm{~d}, J 21.8 \mathrm{~Hz})$, 63.26 (d, J $7.1 \mathrm{~Hz}$ ), 62.80 (d, J $7.6 \mathrm{~Hz}), 54.44$ (d, J $138.4 \mathrm{~Hz}), 16.34,16.30$ ppm. ${ }^{19} \mathrm{~F}$ NMR: $\left(564 \mathrm{MHz}, \mathrm{CDCl}_{3}\right) \delta-$ 114.82 (d, J $5.0 \mathrm{~Hz}$ ) ppm. ${ }^{31} \mathrm{P}$ NMR: $\left(243 \mathrm{MHz}, \mathrm{CDCl}_{3}\right) \delta 21.85$ ppm. HRMS: Calc'd for $\mathrm{C}_{15} \mathrm{H}_{18} \mathrm{FN}_{2} \mathrm{O}_{3} \mathrm{PNa}\left[\mathrm{M}+\mathrm{Na}^{+}\right]$ 347.0931; found 347.0931.

Diethyl (4-fluorophenyl)(5-trifluoropyrimidin-2-yl)methylphosphonate (43)

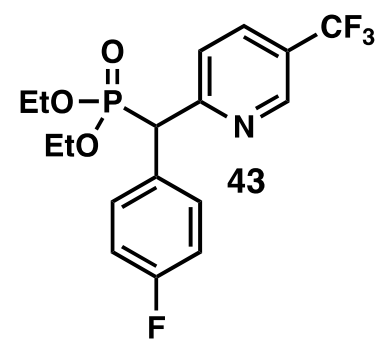

GP-1 was used with commercially available diethyl (4-fluorobenzyl)phosphonate and 2-chloro-5(trifluoromethyl)pyridine. After the addition of NaHMDS, the reaction stirred at $-78{ }^{\circ} \mathrm{C}$ for 1 hour then warmed to room temperature where it stirred for an additional 30 minutes. Purified by silica gel column chromatography using hexanes/EtOAc (0\% to 40\% EtOAc gradient) to give 43 (79.0 mg, $0.201 \mathrm{mmol}, 81 \%$ yield) as a clear colorless oil. TLC: $\mathrm{R}_{\mathrm{f}}=0.29$ (40\% EtOAc in hexanes, UV). ${ }^{1} \mathrm{H} \mathrm{NMR:}\left(500 \mathrm{MHz}, \mathrm{CDCl}_{3}\right) \delta 8.82(\mathrm{dt}, J$ 1.7, $0.8 \mathrm{~Hz}, 1 \mathrm{H}), 7.88(\mathrm{dd}, J$ 8.3, $2.4 \mathrm{~Hz}, 1 \mathrm{H}), 7.77-7.71(\mathrm{~m}, 1 \mathrm{H}), 7.59-7.53(\mathrm{~m}, 2 \mathrm{H}), 7.06-6.98(\mathrm{~m}, 2 \mathrm{H}), 4.76$ (d, J $24.3 \mathrm{~Hz}, 1 \mathrm{H}), 4.12-3.89(\mathrm{~m}, 4 \mathrm{H}), 1.19-1.13(\mathrm{~m}, 6 \mathrm{H})$ ppm. ${ }^{13} \mathrm{C}$ NMR: $\left(151 \mathrm{MHz}, \mathrm{CDCl}_{3}\right) \delta$ 163.16, 161.52, 160.66, 146.27 (d, J $4.6 \mathrm{~Hz}$ ), 134.04, 131.34 (t, J $7.8 \mathrm{~Hz}), 130.55,126.29-122.39(\mathrm{~m}), 123.69$ (d, J $5.1 \mathrm{~Hz}$ ), $115.70(\mathrm{~d}, J 21.5 \mathrm{~Hz}), 63.33(\mathrm{~d}, J 7.0 \mathrm{~Hz}), 62.75(\mathrm{~d}, J 7.1 \mathrm{~Hz}), 53.08$ (d, J $138.2 \mathrm{~Hz}), 16.29,16.25$ ppm. ${ }^{19} \mathrm{~F} \mathrm{NMR:}$ (471 MHz, $\left.\mathrm{CDCl}_{3}\right) \delta-62.43,-114.51(\mathrm{~d}, J 3.6 \mathrm{~Hz})$ ppm. ${ }^{31} \mathrm{P} \mathrm{NMR}:\left(243 \mathrm{MHz}, \mathrm{CDCl}_{3}\right) \delta 22.43$ ppm. HRMS: Calc'd for $\mathrm{C}_{17} \mathrm{H}_{19} \mathrm{~F}_{4} \mathrm{NO}_{3} \mathrm{P}\left[\mathrm{M}+\mathrm{H}^{+}\right]$392.1033; found 392.1037.

Diethyl (4-fluorophenyl)-(2-chloropyridin-4-yl)methylphosphonate (44)

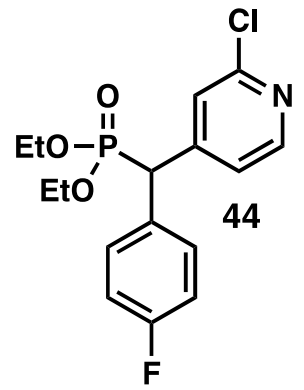

GP-1 was used with commercially available diethyl (4-fluorobenzyl)phosphonate and 2-chloro-4fluoropyridine. After the addition of NaHMDS, the reaction stirred at $-78{ }^{\circ} \mathrm{C}$ for 1 hour then warmed to room temperature where it stirred for an additional 1 hour. Purified by silica gel column chromatography using hexanes/EtOAc ( $0 \%$ to 40\% EtOAc gradient) to give $44(72.0 \mathrm{mg}, 0.201 \mathrm{mmol}, 80 \%$ yield) as a clear colorless oil. *A small amount of the other $\mathrm{S}_{\mathrm{N}} \mathrm{Ar}$ regioisomer was detected and was inseparable from the major product. 
TLC: $R_{f}=0.27$ (30\% EtOAc in hexanes, UV). ${ }^{1} \mathrm{H}$ NMR: $\left(500 \mathrm{MHz}, \mathrm{CDCl}_{3}\right) \delta 8.32$ (d, J $\left.5.2 \mathrm{~Hz}, 1 \mathrm{H}\right), 7.45$ (ddd, J 8.9, 5.2, $1.9 \mathrm{~Hz}, 2 \mathrm{H}), 7.42(\mathrm{t}, J 1.8 \mathrm{~Hz}, 1 \mathrm{H}), 7.38(\mathrm{dt}, J$ 5.2, $1.7 \mathrm{~Hz}, 1 \mathrm{H}), 7.05(\mathrm{t}, J 8.2 \mathrm{~Hz}, 2 \mathrm{H}), 4.35(\mathrm{~d}, J 25.0 \mathrm{~Hz}, 1 \mathrm{H})$, $4.07-3.94(\mathrm{~m}, 3 \mathrm{H}), 3.89-3.79(\mathrm{~m}, 1 \mathrm{H}), 1.19(\mathrm{t}, J 7.1 \mathrm{~Hz}, 3 \mathrm{H}), 1.12(\mathrm{t}, J 7.2 \mathrm{~Hz}, 3 \mathrm{H}) \mathrm{ppm} .{ }^{13} \mathrm{C} \mathrm{NMR}:(126 \mathrm{MHz}$, $\left.\mathrm{CDCl}_{3}\right) \delta 163.38(\mathrm{~d}, J 2.3 \mathrm{~Hz}), 161.41(\mathrm{~d}, J 2.7 \mathrm{~Hz}), 151.90,149.82,149.11(\mathrm{~d}, J 4.5 \mathrm{~Hz}), 131.17(\mathrm{t}, J 7.9 \mathrm{~Hz})$, 130.32 (dd, J 5.9, 3.6 Hz), 124.79 (d, J $8.2 \mathrm{~Hz}), 123.03$ (d, J $6.8 \mathrm{~Hz}), 115.99$ (d, J $21.3 \mathrm{~Hz}), 63.42$ (d, J $6.8 \mathrm{~Hz})$, 62.92 (d, J $7.3 \mathrm{~Hz}$ ), 49.59 (d, J $139.4 \mathrm{~Hz}$ ), 16.27 (d, J $3.2 \mathrm{~Hz}), 16.23$ (d, J 2.7 Hz) ppm. ${ }^{19} \mathrm{~F} \mathrm{NMR:}\left(471 \mathrm{MHz}, \mathrm{CDCl}_{3}\right)$ $\delta$-113.82 (d, J $3.5 \mathrm{~Hz}$ ) ppm. ${ }^{31} \mathrm{P}$ NMR: $\left(243 \mathrm{MHz}, \mathrm{CDCl}_{3}\right) \delta 22.28$ ppm. HRMS: Calc'd for $\mathrm{C}_{16} \mathrm{H}_{19} \mathrm{ClFNO}_{3} \mathrm{P}\left[\mathrm{M}_{+} \mathrm{H}^{+}\right]$ 358.0770; found 358.0776.

Diethyl (2,6-dichloropyridin-4-yl)(4-fluorophenyl)methylphosphonate (45)

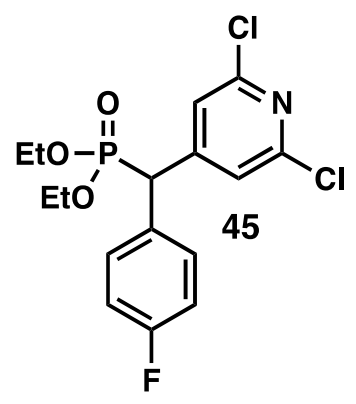

GP-1 was used with commercially available diethyl (4-fluorobenzyl)phosphonate and previously synthesized 68 (2,6-dichloro-4-(methylsulfonyl)pyridine). After the addition of NaHMDS, the reaction stirred at $-78{ }^{\circ} \mathrm{C}$ for 1 hour then warmed to room temperature where it stirred for an additional 2 hours. Purified by silica gel column chromatography using hexanes/EtOAc (0\% to 40\% EtOAc gradient) to give 45 (69.0 mg, $0.171 \mathrm{mmol}$, $68 \%$ yield) as a white solid. TLC: $\mathrm{R}_{f}=0.59$ (60\% EtOAc in hexanes, UV). ${ }^{1} \mathrm{H}$ NMR: $\left(500 \mathrm{MHz}, \mathrm{CDCl}_{3}\right) \delta 7.44(\mathrm{ddt}, J$ 7.0, 5.2, 1.9 Hz, 2H), $7.38(\mathrm{dd}, J 1.8,0.6 \mathrm{~Hz}, 2 \mathrm{H}), 7.11-7.04(\mathrm{~m}, 2 \mathrm{H}), 4.33(\mathrm{~d}, J 25.0 \mathrm{~Hz}, 1 \mathrm{H}), 4.11-3.96(\mathrm{~m}, 3 \mathrm{H})$, $3.87-3.77(\mathrm{~m}, 1 \mathrm{H}), 1.23(\mathrm{td}, J 7.0,0.4 \mathrm{~Hz}, 3 \mathrm{H}), 1.12$ (td, J 7.0, 0.7 Hz, 3H) ppm. ${ }^{13} \mathrm{C} \mathrm{NMR:}\left(126 \mathrm{MHz}^{\mathrm{C}} \mathrm{CDCl}\right) \delta$ 163.51 (d, J $2.7 \mathrm{~Hz}$ ), 161.53 (d, J $2.7 \mathrm{~Hz}$ ), 151.65 (d, J $4.5 \mathrm{~Hz}$ ), 150.80, 131.20 (t, J 7.9 Hz), 129.70 (dd, J 5.9, 3.2 $\mathrm{Hz}), 123.37$ (d, J $7.3 \mathrm{~Hz}$ ), 122.27, 116.18 (d, J $21.3 \mathrm{~Hz}), 63.65$ (d, J $6.8 \mathrm{~Hz}), 63.00$ (d, J $6.8 \mathrm{~Hz}), 49.38$ (d, J 139.9 $\mathrm{Hz}), 16.26(\mathrm{t}, J 5.7 \mathrm{~Hz}) \mathrm{ppm} .{ }^{19} \mathrm{~F} N \mathrm{NMR}:\left(471 \mathrm{MHz}^{\left.\mathrm{C} C \mathrm{CD}_{3}\right)} \delta-113.29(\mathrm{~d}, J 2.6 \mathrm{~Hz}) \mathrm{ppm} .{ }^{31} \mathrm{P} \mathrm{NMR}:\left(243 \mathrm{MHz}, \mathrm{CDCl}_{3}\right)\right.$ $\delta$ 21.60. HRMS: Calc'd for $\mathrm{C}_{16} \mathrm{H}_{18} \mathrm{Cl}_{2} \mathrm{FNO}_{3} \mathrm{P}\left[\mathrm{M}+\mathrm{H}^{+}\right]$392.0380; found 392.0380 .

Diethyl (benzotriazol-2-yl)(4-fluorophenyl)methylphosphonate (46)

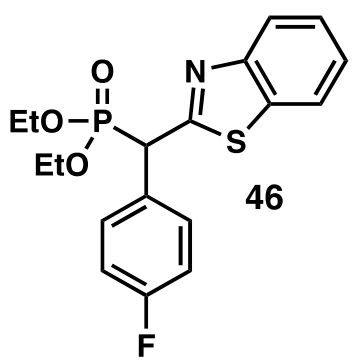

GP-1 was used with commercially available diethyl (4-fluorobenzyl)phosphonate and 2-chlorobenzothiazole. After the addition of NaHMDS, the reaction stirred at $-78{ }^{\circ} \mathrm{C}$ for 1 hour then warmed to room temperature where it stirred for an additional 1 hour. Purified by silica gel column chromatography using hexanes/EtOAc (0\% to $60 \%$ EtOAc gradient) to give $46\left(77.0 \mathrm{mg}, 0.203 \mathrm{mmol}, 81 \%\right.$ yield) as a clear colorless oil. TLC: $\mathrm{R}_{\mathrm{f}}=0.20$ (40\% EtOAc in hexanes, UV). ${ }^{1} \mathrm{H}$ NMR: $\left(600 \mathrm{MHz}, \mathrm{CDCl}_{3}\right) \delta 8.02(\mathrm{~d}, J 8.2 \mathrm{~Hz}, 1 \mathrm{H}), 7.82(\mathrm{dd}, J 8.0,1.2 \mathrm{~Hz}, 1 \mathrm{H}), 7.65$ 
(ddd, J 8.9, 5.1, 2.1 Hz, 2H), 7.44 (ddd, J 8.3, 7.1, 1.3 Hz, 1H), $7.38-7.32(\mathrm{~m}, 1 \mathrm{H}), 7.05(\mathrm{t}, J 8.6 \mathrm{~Hz}, 2 \mathrm{H}), 5.02(\mathrm{~d}, J$ $24.8 \mathrm{~Hz}, 1 \mathrm{H}), 4.19-4.01(\mathrm{~m}, 3 \mathrm{H}), 4.00-3.89(\mathrm{~m}, 1 \mathrm{H}), 1.21(\mathrm{t}, J 7.1 \mathrm{~Hz}, 3 \mathrm{H}), 1.15(\mathrm{t}, J 7.1 \mathrm{~Hz}, 3 \mathrm{H}) \mathrm{ppm} .{ }^{13} \mathrm{C} N M R$ : $\left(151 \mathrm{MHz} \mathrm{CDCl}_{3}\right) \delta 165.80,163.36,161.72,152.80,135.73,131.47$ (t, J $\left.7.4 \mathrm{~Hz}\right), 129.88$ (d, J 4.4 Hz), 126.12, 125.30, 123.26, 121.49, 115.77 (d, J 21.4 Hz), 63.56 (d, J $6.9 \mathrm{~Hz}), 63.42$ (d, J 7.1 Hz), 50.13 (d, J 139.5 Hz), 16.34 (d, J $5.6 \mathrm{~Hz}$ ), 16.28 (d, J $6.3 \mathrm{~Hz}$ ) ppm. ${ }^{19} \mathrm{~F}$ NMR: (471 MHz, $\left.\mathrm{CDCl}_{3}\right) \delta-113.82$ (d, J $3.5 \mathrm{~Hz}$ ) ppm. ${ }^{31} \mathrm{P}$ NMR: (243 $\left.\mathrm{MHz}, \mathrm{CDCl}_{3}\right) \delta 20.25$ ppm. HRMS: Calc'd for $\mathrm{C}_{16} \mathrm{H}_{19} \mathrm{ClFNO}_{3} \mathrm{P}\left[\mathrm{M}+\mathrm{H}^{+}\right]$380.0880; found 380.0877 .

Ethyl 6-cyano-2-(diethoxyphosphonyl)-4-(sodionitronyl)hexa-2,5-dienoate (50)

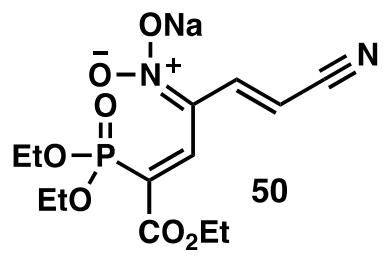

GP-2 was used with commercially available ethyl 2-(diethoxyphosphoryl)acetate and 2-chloro-5-nitropyridine. After reaching room temperature, the reaction stirred for 15 hours (heating the reaction to $60{ }^{\circ} \mathrm{C}$ for 12 hours did not appear to change the reaction profile. Purified by silica gel column chromatography using EtOAc/MeOH (0\% to $10 \% \mathrm{MeOH}$ gradient) to give $50(58.0 \mathrm{mg}, 0.168 \mathrm{mmol}, 67 \%$ yield) as an orange oil that solidified upon standing. Recrystallization using THF afforded a yellow crystalline solid. TLC: $R_{f}=0.2(10 \%$ MeOH in EtOAc, UV). M.P. = > $300{ }^{\circ} \mathrm{C} .{ }^{1} \mathrm{H}$ NMR: $(600 \mathrm{MHz}, \mathrm{MeOD}) \delta 7.93$ (d, J $\left.23.6 \mathrm{~Hz}, 1 \mathrm{H}\right), 7.22$ (d, J $16.0 \mathrm{~Hz}$, $1 \mathrm{H}), 5.84(\mathrm{~d}, J 16.0 \mathrm{~Hz}, 1 \mathrm{H}), 4.23(\mathrm{q}, J 7.1 \mathrm{~Hz}, 2 \mathrm{H}), 4.12$ (apparent p, J $7.1 \mathrm{~Hz}, 4 \mathrm{H}), 1.37-1.31(\mathrm{~m}, 9 \mathrm{H}) \mathrm{ppm} .{ }^{13} \mathrm{C}$ NMR: (151 MHz, MeOD) $\delta 166.86$ (d, J 15.2 Hz), 143.61 (d, J 10.9 Hz), 141.61, 121.06, 120.45 (d, J 21.4 Hz), $106.44(\mathrm{~d}, J 191.8 \mathrm{~Hz}), 84.78,62.42$ (d, J $5.3 \mathrm{~Hz}), 60.67,15.19$ (d, J 6.4 Hz), 13.24 ppm. ${ }^{31} \mathrm{p} \mathrm{NMR:} \mathrm{(243} \mathrm{MHz,}$ MeOD) $\delta 20.12$ ppm. HRMS: Calc'd for $\mathrm{C}_{13} \mathrm{H}_{20} \mathrm{~N}_{2} \mathrm{O}_{7} \mathrm{P}\left[\mathrm{M}+\mathrm{H}^{+}\right]$347.1003; found 347.1010.

\section{Acknowledgements}

We gratefully acknowledge the H. Lee Moffitt Cancer Center \& Research Institute for financial support. This work has also been supported in part by the Chemical Biology Core Facility (NMR, LC-MS, HRMS) at the H. Lee Moffitt Cancer Center \& Research Institute, an NCI designated Comprehensive Cancer Center (P30-CA076292).

\section{Supplementary Material}

Copies of ${ }^{1} \mathrm{H},{ }^{13} \mathrm{C},{ }^{19} \mathrm{~F}$, and ${ }^{31} \mathrm{P}$ NMR are available in the supplementary material. X-Ray crystallographic data for compound 30 (CCDC 2060587) and 50 (CCDC 2061157) are included.

\section{References}

1. De Clercq, E.; Holý, A. Nat. Rev. Drug Discov. 2005, 4 ,928-940. https://doi.org/10.1038/nrd1877

2. Wang, P.-C.; Fang, J.-M.; Tsai, K.-C.; Wang, S.-Y.; Huang, W.-I.; Tseng, Y.-C.; Cheng, Y.-S. E.; Cheng, T.-J. R.; Wong, C.-H. J. Med. Chem. 2016, 59, 5297-5310. https://doi.org/10.1021/acs.jmedchem.6b00029 
3. Warren, T. K.; Jordan, R.; Lo, M. K.; Ray, A. S.; Mackman, R. L.; Soloveva, V.; Siegel, D.; Perron, M.; Bannister, R.; Hui, H. C.; Larson, N.; Strickley, R.; Wells, J.; Stuthman, K. S.; Van Tongeren, S. A.; Garza, N. L.; Donnelly, G.; Shurtleff, A. C.; Retterer, C. J.; Gharaibeh, D.; Zamani, R.; Kenny, T.; Eaton, B. P.; Grimes, E.; Welch, L. S.; Gomba, L.; Wilhelmsen, C. L.; Nichols, D. K.; Nuss, J. E.; Nagle, E. R.; Kugelman, J. R.; Palacios, G.; Doerffler, E.; Neville, S.; Carra, E.; Clarke, M. O.; Zhang, L.; Lew, W.; Ross, B.; Wang, Q.; Chun, K.; Wolfe, L.; Babusis, D.; Park, Y.; Stray, K. M.; Trancheva, I.; Feng, J. Y.; Barauskas, O.; Xu, Y.; Wong, P.; Braun, M. R.; Flint, M.; McMullan, L. K.; Chen, S.-S.; Fearns, R.; Swaminathan, S.; Mayers, D. L.; Spiropoulou, C. F.; Lee, W. A.; Nichol, S. T.; Cihlar, T.; Bavari, S. Nature 2016, 531, 381-385.

https://doi.org/10.1038/nature17180

4. Gagnon, K. J.; Perry, H. P.; Clearfield, A. Chem. Rev. 2012, 112, 1034-1054. https://doi.org/10.1021/cr2002257

5. Yamanaka, K.; Imazato, K.; Takahashi, N. Preparation of organophosphorus compounds as a flame retardant. PCT Intl. Patent WO20180561553, 2018; Chem. Abstr. 2018, 168, 317057.

6. Tang, W.; Zhang, X. Chem. Rev. 2003, 103, 3029-3070. https://doi.org/10.1021/cr020049i

7. Benaglia, M.; Rossi, S. Org. Biomol. Chem. 2010, 8, 3824-3830. https://doi.org/10.1039/C004681G

8. Roch-Neirey, C.; Le Bris, N.; Laurent, P.; Clément, J.-C.; des Abbayes, H. Tetrahedron Lett. 2001, 42, 643645.

https://doi.org/10.1016/S0040-4039(00)02028-1

9. Contrella, N. D.; Sampson, J. R.; Jordan, R. F. Organometallics 2014, 33, 3546-3555. https://doi.org/10.1021/om5004489

10. Engel, R. Chem. Rev. 1977, 77, 349-367. https://doi.org/10.1021/cr60307a003

11. Maji, R.; Mallojjala, S. C.; Wheeler, S. E. Chem. Soc. Rev. 2018, 47, 1142-1158. https://doi.org/10.1039/C6CS00475J

12. Sevrain, C. M.; Berchel, M.; Couthon, H.; Jaffrès, P. A. Beilstein J. Org. Chem. 2017, 13, 2186-2213. https://doi.org/10.3762/bjoc.13.219

13. Boutagy, J.; Thomas, R. Chem. Rev. 1974, 74, 87-99. https://doi.org/10.1021/cr60287a005

14. Gilead Sciences. Viread (tenofovir disoproxil fumarate) [package insert]. U.S. Food and Drug Administration website. https://www.accessdata.fda.gov/drugsatfda_docs/label/2012/022577lbl.pdf Revised January 2012. Accessed January 22, 2021.

15. De Clercq, E. Int. J. Antimicrob. Agents 2009, 33, 307-320. https://doi.org/10.1016/i.ijantimicag.2008.10.010

16. Schwender, C. F.; Beers, S. A.; Malloy, E. A.; Cinicola, J. J.; Wustrow, D. J.; Demarest, K. D.; Jordan, J. Bioorg. Med. Chem. Lett. 1996, 6, 311-314. https://doi.org/10.1016/0960-894X(96)00018-2

17. Younes, S.; Baziard-Mouysset, G.; de Saqui-Sannes, G.; Stigliani, J. L.; Payard, M.; Bonnafous, R.; TisneVersailles, J. Eur. J. Med. Chem. 1993, 28, 943-948. https://doi.org/10.1016/0223-5234(93)90049-K

18. Khurmi, N. S.; Bowles, M. J.; O'Hara, M. J.; Lahiri, A.; Raftery, E. B. Int. J. Cardiol. 1985, 9, 289-302. https://doi.org/10.1016/0167-5273(85)90027-0 
19. Takada, T.; Miyawaki, N.; Kageyama, M.; Matsuno, K.; Ishida, N.; Yamauchi, H.; Iso, T. J. Cardiovasc. Pharmacol. 1991, 18.

https://journals.Iww.com/cardiovascularpharm/Abstract/1991/12000/Antihypertensive Effect of a Nove Calcium.11.aspx

20. Yamada, H.; Tanaka, K.; Adachi, H.; Yamada, S.; Shimoda, S. Preparation of 2-benzoylpyrimidine derivatives as herbicides and agrochemical fungicides. PCT Intl. Patent WO9408975, 1994; Chem. Abstr. 1994, 121, 230784

21. Chen, Z.; Zeng, M.; Song, B.; Hou, C.; Hu, D.; Li, X.; Wang, Z.; Fan, H.; Bi, L.; Liu, J.; Yu, D.; Jin, L.; Yang, S. PLoS One 2012, 7, e37944.

https://doi.org/10.1371/journal.pone.0037944

22. Gibadullina, E.; Nguyen, T. T.; Strelnik, A.; Sapunova, A.; Voloshina, A.; Sudakov, I.; Vyshtakalyuk, A.; Voronina, J.; Pudovik, M.; Burilov, A. Eur. J. Med. Chem. 2019, 184, 111735.

https://doi.org/10.1016/i.ejmech.2019.111735

23. Zhang, B.; Liu, L.; Mao, S.; Zhou, M.-D.; Wang, H.; Li, L. Eur. J. Org. Chem. 2019, 3898-3907. https://doi.org/10.1002/ejoc.201900606

24. Xiong, B.; Wang, G.; Zhou, C.; Liu, Y.; Xu, W.; Xu, W.-Y.; Yang, C.-A.; Tang, K.-W. Eur. J. Org. Chem. 2019, 3273-3282. https://doi.org/10.1002/ejoc.201900419

25. Babu, B. H.; Prasad, G. S.; Raju, C. N.; Basaveswara Rao, M. V. Curr. Org. Synth. 2017, 14, 883-903. https://doi.org/10.2174/1570179414666161230144455

26. Gavara, L.; Petit, C.; Montchamp, J.-L. Tetrahedron Lett. 2012, 53, 5000-5003. https://doi.org/10.1016/i.tetlet.2012.07.019

27. Minami, T.; Isonaka, T.; Okada, Y.; Ichikawa, J. J. Org. Chem. 1993, 58, 7009-7015. https://doi.org/10.1021/jo00077a018

28. Rout, L.; Regati, S.; Zhao, C.-G. Adv. Synth. \& Catal. 2011, 353, 3340-3346. https://doi.org/10.1002/adsc.201100605

29. Pallikonda, G.; Chakravarty, M. Eur. J. Org. Chem. 2013, 944-951. https://doi.org/10.1002/ejoc.201201352

30. Hlavinka, M. L.; Hagadorn, J. R. Organometallics 2007, 26, 4105-4108. https://doi.org/10.1021/om700475t

31. Montel, S.; Raffier, L.; He, Y.; Walsh, P. J. Org. Lett. 2014, 16, 1446-1449. https://doi.org/10.1021/ol5002413

32. Petrova, I.; Momchilova, S.; Vasilev, N. Phosphorus, Sulfur Silicon Relat. Elem. 1992, 68, $45-52$. https://doi.org/10.1080/10426509208038370

33. Wang, H.; Huang, L.; Cao, X.; Liang, D.; Peng, A.-Y. Org. Biomol. Chem. 2017, 15, 7396-7403. https://doi.org/10.1039/C7OB01436H

34. He, T.-J.; Zhu, S.; Lu, X.-W.; Wu, Y.; Li, Y. Eur. J. Org. Chem. 2015, 647-654. https://doi.org/10.1002/ejoc.201403287

35. Mąkosza, M.; Sulikowski, D. J. Org. Chem. 2009, 74, 3827-3832. https://doi.org/10.1021/jo900204e

36. Fujii, K.; Ito, S.; Mikami, K. J. Org. Chem. 2019, 84, 12281-12291. https://doi.org/10.1021/acs.joc.9b01402

37. Bordwell, F. G. Acc. Chem. Res. 1988, 21, 456-463. https://doi.org/10.1021/ar00156a004 
38. Blasdel, L. K.; Myers, A. G. Org. Lett. 2005, 7, 4281-4283. https://doi.org/10.1021/ol051785m

39. Tulyasheva, M.; Rasulev, B.; Tojiboev, A.; Turgunov, K.; Tashkhodjaev, B.; Abdullaev, N.; Shakhidoyatov, K. Molecules 2005, 10, 1209-1217.

https://doi.org/10.3390/10091209

40. Chiacchio, M. A.; Iannazzo, D.; Romeo, R.; Giofrè, S. V.; Legnani, L. Curr. Med. Chem. 2019, 26, 7166-7195. https://doi.org/10.2174/0929867325666180904125400

41. Al-Zaydi, K. M.; Khalil, H. H.; El-Faham, A.; Khattab, S. N. Chem. Cent. J. 2017, 11, 39. https://doi.org/10.1186/s13065-017-0267-3

42. Hasník, Z.; Pohl, R.; Hocek, M. Tetrahedron Lett. 2010, 51, 2464-2466. https://doi.org/10.1016/j.tetlet.2010.02.167

43. Van der Plas, H. C. Acc. Chem. Res. 1978, 11, 462-468.

https://doi.org/10.1021/ar50132a005

44. Haynes, L. W.; Pett, V. B. J. Org. Chem. 2007, 72, 633-635. https://doi.org/10.1021/jo0620031

45. Kaur, S.; Kumari, P.; Singh, G.; Bhatti, R.; Singh, P. ACS Omega 2018, 3, 5825-5845. https://doi.org/10.1021/acsomega.8b00445

46. Robke, L.; Laraia, L.; Carnero Corrales, M. A.; Konstantinidis, G.; Muroi, M.; Richters, A.; Winzker, M.; Engbring, T.; Tomassi, S.; Watanabe, N.; Osada, H.; Rauh, D.; Waldmann, H.; Wu, Y.-W.; Engel, J. Angew. Chem. Int. Ed. 2017, 56, 8153-8157. https://doi.org/10.1002/anie.201703738

47. Parra, J.; Mercader, J. V.; Agulló, C.; Abad-Fuentes, A.; Abad-Somovilla, A. Tetrahedron 2011, 67, 624-635. https://doi.org/10.1016/i.tet.2010.11.054

48. Boudet, N.; Dubbaka, S. R.; Knochel, P. Org. Lett. 2008, 10, 1715-1718. https://doi.org/10.1021/ol800353s 